The University of Maine

DigitalCommons@UMaine

Earth Science Faculty Scholarship

Earth Sciences

6-1-1992

\title{
Thermal and Barometric Constraints on the Intrusive and Unroofing History of the Black Mountains: Implications for Timing, Initial Dip, and Kinematics of Detachment Faulting in the Death-Valley Region, California
}

Daniel K. Holm

J. Kent Snow

Daniel R. Lux

University of Maine - Main, dlux@maine.edu

Follow this and additional works at: https://digitalcommons.library.umaine.edu/ers_facpub

Part of the Earth Sciences Commons

\section{Repository Citation}

Holm, Daniel K.; Snow, J. Kent; and Lux, Daniel R., "Thermal and Barometric Constraints on the Intrusive and Unroofing History of the Black Mountains: Implications for Timing, Initial Dip, and Kinematics of Detachment Faulting in the Death-Valley Region, California" (1992). Earth Science Faculty Scholarship. 107.

https://digitalcommons.library.umaine.edu/ers_facpub/107

This Article is brought to you for free and open access by DigitalCommons@UMaine. It has been accepted for inclusion in Earth Science Faculty Scholarship by an authorized administrator of DigitalCommons@UMaine. For more information, please contact

um.library.technical.services@maine.edu. 


\section{THERMAL AND BAROMETRIC CONSTRAINTS ON THE INTRUSIVE AND UNROOFING HISTORY OF THE BLACK MOUNTAINS: IMPLICATIONS FOR TIMING, INITIAL DIP, AND KINEMATICS OF DETACHMENT FAULTING IN THE DEATH VALLEY REGION, CALIFORNIA}

Daniel K. Holm ${ }^{1}$ and J. Kent Snow ${ }^{2}$

Department of Earth and Planetary Sciences, Harvard

University, Cambridge, Massachusetts

Daniel R. Lux

Department of Geology, University of Maine, Orono

Abstract. Unroofing of the Black Mountains, Death Valley, California, has resulted in the exposure of $1.7 \mathrm{Ga}$ crystalline basement, late Precambrian amphibolite facies metasedimentary rocks, and a Tertiary magmatic complex. The ${ }^{40} \mathrm{Ar} /{ }^{39} \mathrm{Ar}$ cooling ages, obtained from samples collected across the entire length of the range $(>55 \mathrm{~km})$, combined with geobarometric results from synextensional intrusions, provide time-depth constraints on the Miocene intrusive history and extensional unroofing of the Black Mountains. Data from the southeastern Black Mountains and adjacent Greenwater Range suggest unroofing from shallow depths between 9 and $10 \mathrm{Ma}$. To the northwest in the crystalline core of the range, biotite plateau ages from $\sim 13$ to $6.8 \mathrm{Ma}$ from rocks making up the Death Valley turtlebacks indicate a midcrustal residence (with temperatures $>300^{\circ} \mathrm{C}$ ) prior to extensional unroofing. Biotite ${ }^{40} \mathrm{Ar} /{ }^{39} \mathrm{Ar}$ ages from both Precambrian basement and Tertiary plutons reveal a diachronous cooling pattern of decreasing ages toward the northwest, subparallel to the regional extension direction. Diachronous cooling was accompanied by dike intrusion which also decreases in age toward the northwest. The cooling age pattem and geobarometric constraints in crystalline rocks of the Black Mountains suggest denudation of $10-15 \mathrm{~km}$ along a northwest directed detachment system, consistent with regional reconstructions of Tertiary extension and with unroofing of a northwest deepening crustal section. Mica cooling ages that deviate from the northwest younging trend are consistent with northwestward transport of rocks initially at shallower crustal levels onto deeper levels along splays of the detachment. The well-known Amargosa chaos and perhaps the Badwater turtleback are examples of this "splaying" process.

Considering the current distance of the structurally deepest samples away from moderately to steeply east tilted Tertiary strata in the southeastern Black Mountains, these data indicate an average initial dip of the detachment system of the order of $20^{\circ}$, similar to that determined for detachment faults in west

\footnotetext{
${ }^{1}$ Now at Department of Geology, Kent State University, Kent, Ohio.

2 Now at Division of Geology and Planetary Sciences, California Institute of Technology, Pasadena, California .
}

Copyright 1992 by the American Geophysical Union.

Paper number 92TC00211

0278-7407/92/92TC-0021\$10.00 central Arizona and southeastern California. Beginning with an initially listric geometry, a pattern of footwall unroofing accompanied by dike intrusion progresses northwestward. This pattern may be explained by a model where migration of footwall flexures occur below a scoop-shaped hanging wall block. One consequence of this model is that gently dipping ductile fabrics developed in the middle crust steepen in the upper crust during unloading. This process resolves the low initial dips obtained here with mapping which suggests transport of the upper plate on moderately to steeply dipping surfaces in the middle and upper crust.

\section{INTRODUCTION}

Determining the timing, pattern, and amount of unroofing during orogeny is fundamental to understanding processes of lithospheric deformation. In the Basin and Range province, geologic studies using fluid inclusions [Parry and Bruhn, 1987] and balanced and reconstructed cross sections [Bartley and Wernicke, 1984; Wernicke and Axen, 1988] indicate 10-15 km, and perhaps up to $20 \mathrm{~km}$, of footwall unroofing for some mountain ranges. As these depths generally correspond to temperatures between $200^{\circ} \mathrm{C}$ and $500^{\circ} \mathrm{C},{ }^{40} \mathrm{Ar} /{ }^{39} \mathrm{Ar}$ thermochronologic analyses of minerals with closure temperatures in this range provide a test of the amount and timing of unroofing during Cenozoic extension [Foster et al., 1990; Richard et al., 1990]. With a regional distribution of ages, thermochronology can also be used to determine the areal pattern of cooling, and thus provide a powerful test of structural models of extension.

The Black Mountains of Death Valley, California (Figure 1) are centrally located in the Death Valley extended terrain between the Spring Mountains to the east and the Sierra Nevada to the west. Isotopic, field, and petrologic studies [Asmerom et al., 1990; Holm and Wernicke, 1990] show the Black Mountains to consist predominantly of a Miocene midcrustal magmatic system (intermediate-mafic to silicic) intruded into Proterozoic basement and lesser amounts of miogeoclinal strata metamorphosed to amphibolite facies [Otton, 1977]. Although ${ }^{40} \mathrm{Ar} /{ }^{39} \mathrm{Ar}$ thermochronologic studies in some surrounding ranges have proven to be problematical [e.g., DeWitt et al., 1988], preliminary results from the Black Mountains metamorphic core complex yielded well-behaved ${ }^{40} \mathrm{Ar} / 39 \mathrm{Ar}$ systematics in both Proterozoic basement rocks and Tertiary plutons [Holm et al., 1989; Asmerom et al., 1990; McKenna, 1990]. Thus the Black Mountains provide an excellent opportunity to study the thermal history of a range block unroofed during Tertiary extension. We present ${ }^{40} \mathrm{Ar} /{ }^{39} \mathrm{Ar}$ cooling age data and barometry on synextensional intrusions and crystalline basement rocks from 18 localities distributed throughout the Black Mountains. These thermochronologic and barometric results place important constraints on the time, amount, and style of intrusion and unroofing of footwall rocks exposed by crustal extension in the Death Valley region.

\section{GEOLOGIC FRAMEWORK}

Crustal extension in the Death Valley region has occurred principally between $15 \mathrm{Ma}$ and the present. Reconstruction of Neogene extension in the region between the stable Spring Mountains block and the Sierra Nevada restores range blocks now scattered over an area $150 \mathrm{~km}$ wide into an area less than $10 \mathrm{~km}$ wide [Wernicke et al., 1988; Snow and Wernicke, 


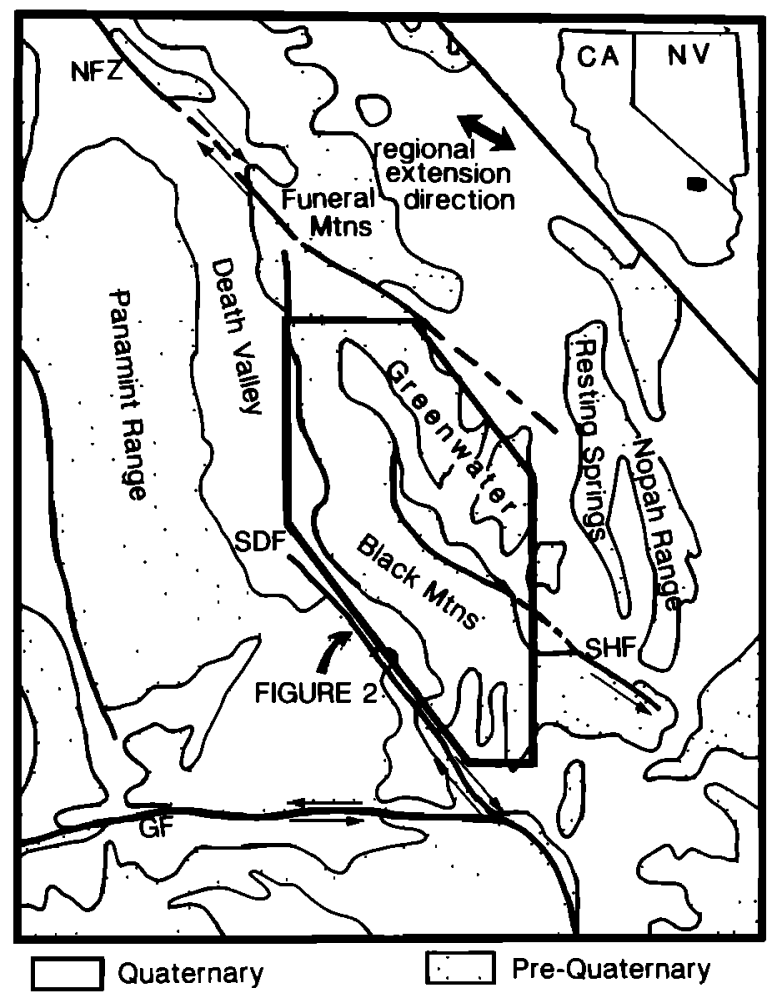

Fig. 1. Index map of the Death Valley region depicting ranges and major faults. Abbreviations are NFZ, Northern Death Valley-Furnace Creek Fault zone; SDF, Southem Death Valley fault; SHF, Sheephead fault; GF, Garlock fault.

1989]. According to these studies, regional westward migration of extension along down-to-the-west detachment faults resulted in the sequential detachment of crustal-scale slivers from a westward migrating hanging wall block [e.g., Asmerom et al., 1990]. Other studies in the region, however, advocate much less extension and favor the evolution of range blocks semiindependently of each other, each with separate deformational and thermal histories [e.g., Wright, 1989].

The Black Mountains lie on the east flank of Death Valley, California (Figure 1). Unroofing of footwall rocks on the westem portion of the range has resulted in the exposure of a series of northwest plunging topographic and structural domes known as the Death Valley "turtlebacks" (Figure 2) [Curry, 1938; Wright et al., 1974a]. These features are composed predominantly of $1.7 \mathrm{Ga}$ gneissic and schistose basement and a carapace of deformed and metamorphosed Eocambrian carbonate. In the core of the Black Mountains and largely surrounding the turtlebacks to the east is a batholith of gabbroic and dioritic composition. A recent isotopic study indicates that this intrusion (the Willow Spring Pluton) is mid-Miocene in age (11.6 $\pm 0.2 \mathrm{Ma}$ [Asmerom et al., 1990]) and thus was emplaced during large-scale extensional tectonism in the region [Cemen et al., 1985]. Intruded into the pluton and Precambrian basement rocks is a silicic complex of granitic to monzonitic composition.

The Black Mountains core described above is structurally overlain along normal faults by the Amargosa chaos [Noble, 1941; Wright and Troxel, 1984], a highly extended mass of unmetamorphosed miogeoclinal strata of Eocambrian and
Cambrian age and Tertiary volcanic and sedimentary rocks (Figure 2). The crystalline terrain was unroofed along these faults in late Miocene and younger time akin to other metamorphic core complexes in the Cordilleran orogen. Holm and Wemicke [1990] proposed that rocks of the Amargosa chaos have been translated $15-20 \mathrm{~km}$ northwestward from an original position in the southeastem Black Mountains (Figure 2). Accordingly, the chaos would represent a stranded portion of the hanging wall of an initially westerly dipping detachment fault along which the Black Mountains were denuded during late Miocene time. The predominantly shallow eastward dip of the fault currently exposed in the eastern Black Mountains would reflect eastward tilting of the range as the footwall was progressively denuded to the west. On the basis of the current configuration of the crustal section and on geobarometry of the Willow Spring Pluton, Holm and Wernicke [1990] suggested a paleodepth range of $10-30 \mathrm{~km}$ for the western portion of the Black Mountains prior to extension. This tectonic scenario for formation of the Black Mountains is consistent with previous reconstructions in the Death Valley region which suggest transport of the Panamint Mountains on the western side of Death Valley (Figure 1) off the top of the Black Mountains during Tertiary extension [Stewart, 1983; Snow and Wernicke, 1989]. In contrast to this scenario, Wright et al. [1987] interpret the Amargosa chaos as overlying a northwesterly moving lower plate with both top-to-the-east denudation of the eastem Black Mountains and top-to-the-west denudation of the western Black Mountains.

\section{ANALYTICAL METHODS}

In order to reveal the cooling age pattern across the Black Mountains, samples were collected from widely spaced localities throughout the range in both Tertiary plutonic rocks and Precambrian basement. Because of the extensive synextensional intrusions located in the central Black Mountains, more samples from different rock types were collected there in order to differentiate between cooling ages related to tectonic unroofing, to postmagmatic cooling, or to thermal resetting. Eighteen localities were sampled across an approximately $55 \mathrm{~km}$ northwest trending traverse along the length of the mountain range. From these samples, 30 age determinations were made on five different mineral systems and one whole rock separate (Table 1).

Minerals were separated using standard magnetic and heavy liquid separation techniques and hand picking. Sample preparation, irradiation, and analytical procedures for ${ }^{40} \mathrm{Ar} /{ }^{39} \mathrm{Ar}$ incremental release dating were described by Lux [1986]. Samples were irradiated in the University of Michigan reactor. Variations in neutron flux during irradiation were monitored with a biotite mineral standard (University of Maine laboratory standard, 247.6 Ma). Plateau ages were calculated from consecutive gas increments that together constitute $>60 \%$ of the total gas released. Uncertainties are reported at the $2 \sigma$ level and include the uncertainty in the flux measurement ( $\mathrm{J}$ value). Analytical results for each sample are given in the Appendix ${ }^{1}$.

Unaltered samples of the Smith Mountain Granite were studied petrographically to select those with the required phase assemblage for Al-in-homblende geobarometry. The total $\mathrm{Al}$

${ }^{1}$ Appendix is available with entire manuscript on microfiche. Order from American Geophysical Union, N.W Washington, D. C. 20009. Document T92-002;\$2.50. Payment must accompany order. 


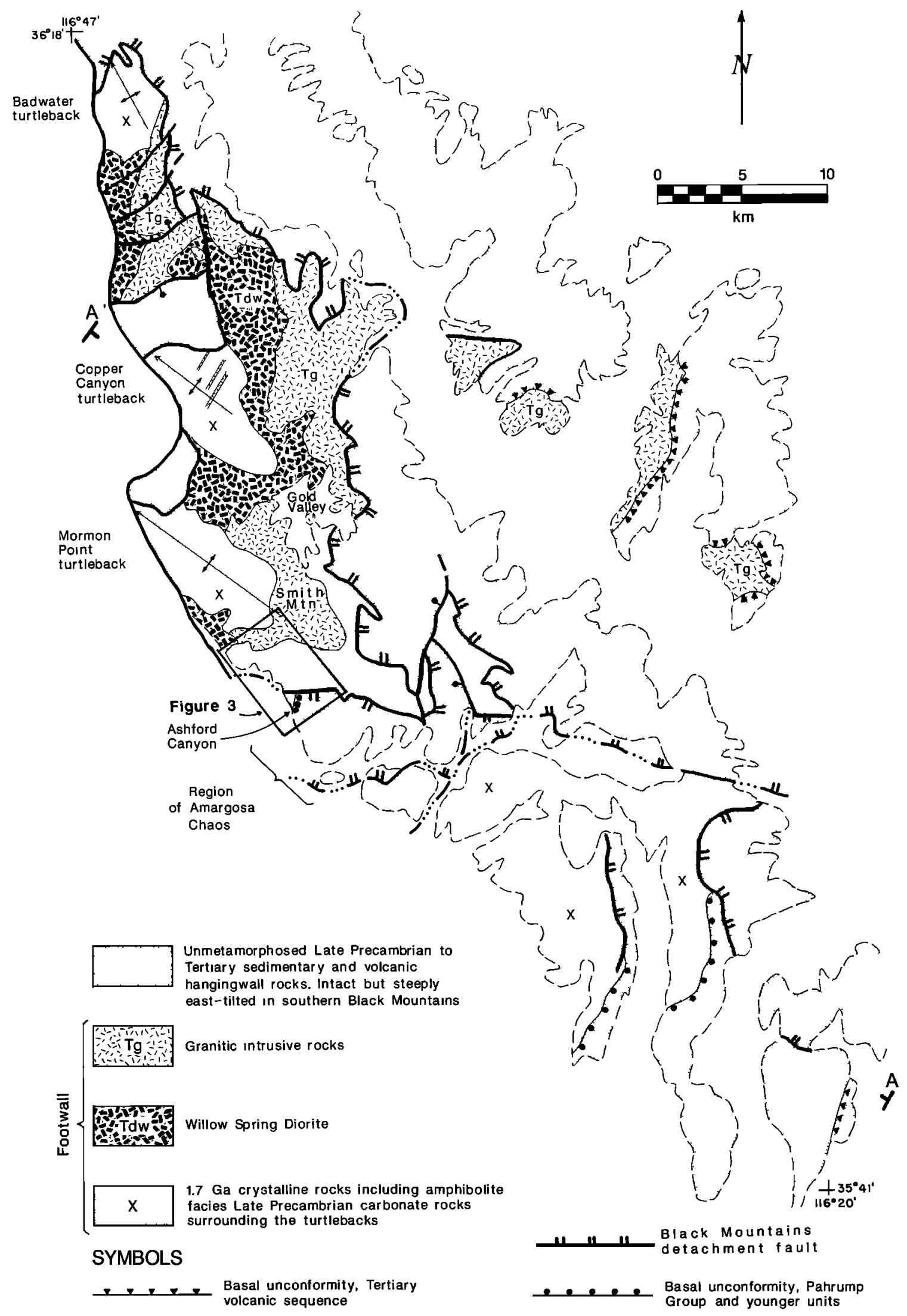

Fig. 2. Geologic map of the Black Mountains and Greenwater Range simplified after Streitz and Stinson [1974], Drewes [1963], Wright and Troxel [1984], Otton [1977] and Holm and Wernicke [1990]. 
Table 1. Summary of Black Mountains ${ }^{40} \mathrm{Ar} /{ }^{39} \mathrm{Ar}$ Data

\begin{tabular}{|c|c|c|c|c|c|}
\hline Sample & Rock Type & Locality & Mineral & Elevation, $\mathbf{m}$ & Age $^{*}, \mathrm{Ma}$ \\
\hline \multicolumn{6}{|c|}{ Southeastern Black Mountains } \\
\hline $\begin{array}{l}\text { IH1-BIO } \\
\text { RH-BIO }\end{array}$ & $\begin{array}{l}\text { pC basement } \\
\text { pC basement }\end{array}$ & $\begin{array}{l}116^{\circ} 25.6^{\prime} \mathrm{W}, 35^{\circ} 52.5^{\prime} \mathrm{N} \\
116^{\circ} 30.0^{\prime} \mathrm{W}, 35^{\circ} 55.0^{\prime} \mathrm{N}\end{array}$ & $\begin{array}{l}\text { biotite } \\
\text { biotite }\end{array}$ & $\begin{array}{r}1,119 \\
671\end{array}$ & $\begin{array}{l}234.3 \pm 2.5(\mathrm{tg}) \\
232.3 \pm 5.9(\mathrm{ti})\end{array}$ \\
\hline \multicolumn{6}{|c|}{ Ashford Canyon } \\
\hline $\begin{array}{l}\text { AM-UNC-M } \\
\text { AM2a-M }\end{array}$ & $\begin{array}{l}\text { p€ basement } \\
\text { pC basement }\end{array}$ & $\begin{array}{l}116^{\circ} 39.6^{\prime} \mathrm{W}, 35^{\circ} 56.4^{\prime} \mathrm{N} \\
116^{\circ} 40.2^{\prime} \mathrm{W}, 35^{\circ} 57.5^{\prime} \mathrm{N}\end{array}$ & $\begin{array}{l}\text { muscovite } \\
\text { muscovite }\end{array}$ & $\begin{array}{l}195 \\
317\end{array}$ & $\begin{array}{l}1411.6 \pm 10.7(\mathrm{tg}) \\
283.2 \pm 4.1(\mathrm{ti})\end{array}$ \\
\hline \multicolumn{6}{|c|}{ Central Black Mountains Core } \\
\hline TPG-SM & granite & $116^{\circ} 40.0^{\prime} \mathrm{W}, 36^{\circ} 02.7^{\prime} \mathrm{N}$ & $\begin{array}{l}\text { homblende } \\
\text { biotite }\end{array}$ & 988 & $\begin{array}{l}8.7 \pm 0.1(t i) \\
8.2 \pm 0.1(t i)\end{array}$ \\
\hline CCR-AR & gabbro-diorite & $116^{\circ} 41.6^{\prime} \mathrm{W}, 36^{\circ} 06.1^{\prime} \mathrm{N}$ & homblende & 1,585 & $10.06 \pm 0.39(\mathrm{tp})$ \\
\hline TPL-BIO & latite dike & $116^{\circ} 40.5^{\prime} \mathrm{W}, 36^{\circ} 03.0^{\prime} \mathrm{N}$ & biotite & 921 & $7.85 \pm 0.18(\mathrm{tp})$ \\
\hline $89-\mathrm{CC}$ & p $€$ basement & $116^{\circ} 44.1^{\prime} \mathrm{W}, 36^{\circ} 06.6^{\prime} \mathrm{N}$ & $\begin{array}{l}\text { homblende } \\
\text { biotite }\end{array}$ & -60 & $\begin{aligned} &>14.31 \pm 0.81(\mathrm{tg}) \\
& 6.63 \pm 0.13(\mathrm{tp})\end{aligned}$ \\
\hline $988-25$ & gabbro-diorite & $116^{\circ} 40.4^{\prime} \mathrm{W}, 36^{\circ} 03.1^{\prime} \mathrm{N}$ & $\begin{array}{l}\text { homblende } \\
\text { biotite }\end{array}$ & 975 & $\begin{array}{r}10.16 \pm 0.20(\mathrm{tp}) \\
8.39 \pm 0.13(\mathrm{tp})\end{array}$ \\
\hline 89-MP & p€ basement & $116^{\circ} 45.1^{\prime} \mathrm{W}, 36^{\circ} 02.0^{\prime} \mathrm{N}$ & $\begin{array}{l}\text { homblende } \\
\text { biotite }\end{array}$ & 61 & $\begin{array}{r}9.94 \pm 0.44 \text { (tp) } \\
8.03 \pm 0.14 \text { (tp) }\end{array}$ \\
\hline 988-20 & gabbro-diorite & $116^{\circ} 40.4^{\prime} \mathrm{W}, 36^{\circ} 03.1^{\prime} \mathrm{N}$ & $\begin{array}{l}\text { homblende } \\
\text { biotite } \\
\text { plagioclase } 1 \\
\text { plagioclase } 2 \\
\text { orthoclase }\end{array}$ & 975 & $\begin{array}{r}10.42 \pm 0.31 \text { (tp) } \\
8.36 \pm 0.17 \text { (tp) } \\
6.70 \pm 0.61 \text { (tp) } \\
5.89 \pm 0.51 \text { (tp) } \\
7.20 \pm 0.30 \text { (ti) }\end{array}$ \\
\hline ССТВ-B & felsic dike & $116^{\circ} 42.3^{\prime} \mathrm{W}, 36^{\circ} 07.1^{\prime} \mathrm{N}$ & biotite & 1,067 & $6.90 \pm 0.20(\mathrm{ti})$ \\
\hline TQM-HB & granite & $116^{\circ} 37.6^{\prime} \mathrm{W}, 36^{\circ} 08.4^{\prime} \mathrm{N}$ & homblende & 1,670 & $8.69 \pm 0.31(\mathrm{tp})$ \\
\hline DH-3780 & $\begin{array}{l}\text { gabbro-diorite } \\
\text { (deformed) }\end{array}$ & $116^{\circ} 40.4^{\prime} \mathrm{W}, 36^{\circ} 08.0^{\prime} \mathrm{N}$ & $\begin{array}{l}\text { homblende } \\
\text { biotite }\end{array}$ & 1,152 & $\begin{array}{l}8.05 \pm 0.28(\mathrm{tp}) \\
7.00 \pm 0.10(\mathrm{ti})\end{array}$ \\
\hline DH-2650 & $\begin{array}{l}\text { gabbro-diorite } \\
\text { (deformed) }\end{array}$ & $116^{\circ} 41.9^{\prime} \mathrm{W}, 36^{\circ} 07.5^{\prime} \mathrm{N}$ & $\begin{array}{l}\text { homblende } \\
\text { biotite }\end{array}$ & 808 & $\begin{array}{l}8.90 \pm 0.60(\mathrm{ti}) \\
6.66 \pm 0.12(\mathrm{tp})\end{array}$ \\
\hline \multicolumn{6}{|c|}{ Northern Black Mountains } \\
\hline $90-38$ & diorite dike & $116^{\circ} 45.0^{\prime} \mathrm{W}, 36^{\circ} 16.3^{\prime} \mathrm{N}$ & whole rock & 750 & $6.31 \pm 0.21(t p)$ \\
\hline BWT-B & p€ basement & $116^{\circ} 45.6^{\prime} \mathrm{W}, 36^{\circ} 17.1^{\prime} \mathrm{N}$ & biotite & 265 & $13.23 \pm 0.23(t p)$ \\
\hline DH-BWT-2 & pC basement & $116^{\circ} 45.0^{\prime} \mathrm{W}, 36^{\circ} 16.3^{\prime} \mathrm{N}$ & $\begin{array}{l}\text { muscovite } \\
\text { biotite }\end{array}$ & 732 & $\begin{array}{l}24.00 \pm 0.40 \text { (ti) } \\
12.70 \pm 0.20 \text { (ti) }\end{array}$ \\
\hline TOM-GW-B & granite & $\begin{array}{r}\text { Green } \\
116^{\circ} 218^{\prime} \mathrm{W}, 35^{\circ} 59.9^{\prime} \mathrm{N}\end{array}$ & $\begin{array}{l}\text { nge } \\
\text { biotite }\end{array}$ & 902 & $9.76 \pm 0.25(\mathrm{tp})$ \\
\hline
\end{tabular}

* All tp (plateau age) and ti (intercept age) are concordant within error when both ages exist for individual samples; tg represents total gas age; $p \in$ is Precambrian.

content in rims of homblende grains in these samples was obtained using a Cameca three-spectrometer CAMEBAX electron microprobe at Harvard University.

\section{THERMOCHRONOLOGY RESULTS}

Previous K-Ar isotopic studies of the Black Mountains concentrated on volcanic rocks which flank the eastern and northern sides of the crystalline terrane [Fleck, 1970]. However, Armstrong [1970] reported K-Ar ages from Tertiary intrusive rocks of $7.5 \pm 0.3 \mathrm{Ma}$ (biotite in diorite) and $6.3 \pm$ $0.4 \mathrm{Ma}$ (granite porphyry whole rock). The results of this study are discussed below with respect to the regional distribution of sample localities summarized in Table 1. Plate 1 is a summary diagram of the thermochronologic data presented in this paper. The ages are plotted on a map of the
Black Mountains which is the same as Figure 2 but without the geological patterns. No diffusion experiments to determine mineral closure temperatures were carried out in this study, and standard closure temperatures of $500^{\circ} \pm 25^{\circ} \mathrm{C}$ (homblende), $350^{\circ}$ $\pm 25^{\circ} \mathrm{C}$ (muscovite), and $300^{\circ} \pm 25^{\circ} \mathrm{C}$ (biotite) are assumed to interpret the data [McDougall and Harrison, 1988]. Interpretation of feldspar release spectra and closure temperature are discussed in the text.

Southeastern Black Mountains. Two ages were obtained from coarsely crystalline mica schists and quartz-feldspar gneisses from Precambrian basement in the southeastern Black Mountains. Biotite separates from samples IH1-BIO and RHBIO yielded similar release spectra and total gas ages of $234.3 \pm$ $2.5 \mathrm{Ma}$ and $230.8 \pm 6.1 \mathrm{Ma}$ respectively. Neither sample yielded a plateau age, but both show a monotonic increase in age (from 210 to $250 \mathrm{Ma}$ ) in progressively higher temperature 
increments. Sample RH-BIO yielded an isotope correlation intercept age of $232.3 \pm 5.9 \mathrm{Ma}$ with a ${ }^{40} \mathrm{Ar} /{ }^{36} \mathrm{Ar}$ initial ratio of $304.5 \pm 38.9$. The similar, although somewhat disturbed, release spectra and total gas ages of these samples, as well as the concordant intercept age for one of the samples, lead us to conclude that this region of the Black Mountains has remained below $300^{\circ} \mathrm{C}$ since $230-235 \mathrm{Ma}$.

Ashford Canyon. Two Precambrian basement samples were collected from the vicinity of Ashford Canyon where late Precambrian Pahrump Group strata rest depositionally on basement (Figure 2). Sample AM-UNC-M is located $\sim 30 \mathrm{~m}$ below the nonconformity (Figure 3). A muscovite separate from AM-UNC-M yielded a total gas age of $1411.6 \pm 10.7$ $\mathrm{Ma}$ and a release spectra in which five increments (with over $65 \%$ of the total gas) give ages between 1360 and $1400 \mathrm{Ma}$. We interpret this spectrum to indicate cooling below $350^{\circ} \mathrm{C}$ at about $1380 \pm 20 \mathrm{Ma}$. A muscovite separate from sample AM2a-M (Figure 3) yielded a saddle-shaped spectrum with an age minimum of $279.3 \pm 1.9 \mathrm{Ma}$. Saddle-shaped spectra are a typical sign of excess argon [McDougall and Harrison, 1988], and the ${ }^{40} \mathrm{Ar} /{ }^{36} \mathrm{Ar}$ initial ratio of $718.3 \pm 47.2$ for this sample confirms this. However, an intercept age of $283.2 \pm 4.1 \mathrm{Ma}$ indicates that the age minimum for this spectrum may be a meaningful cooling age. In addition, when a ${ }^{40} \mathrm{Ar} /{ }^{36} \mathrm{Ar}$ initial ratio of 718.3 is assumed, the release spectrum gives a total gas age of $284 \mathrm{Ma}$ with over $90 \%$ of the gas (eight increments) falling between 280 and $300 \mathrm{Ma}$.

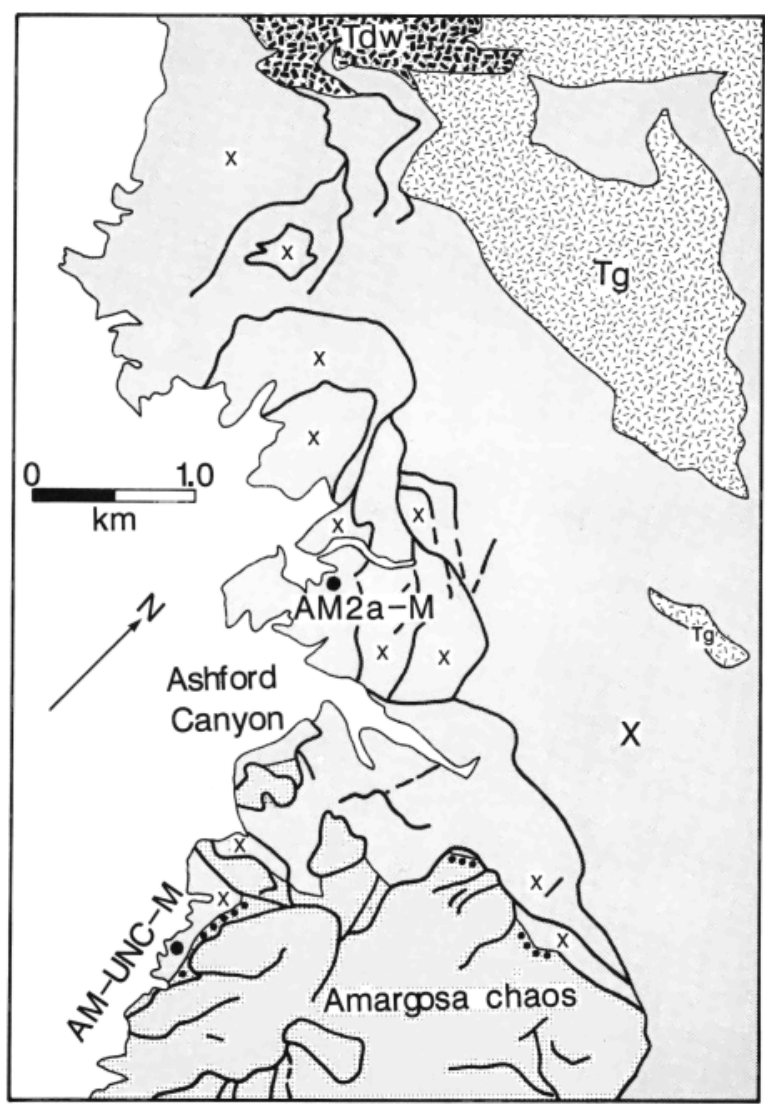

Fig. 3. Geologic map of Ashford Canyon region showing sample localities (simplified after Wright and Troxel [1984]). Patterned after Figure 2.
Central Black Mountains core. Eleven samples were collected from the central Black Mountains crystalline core (Table 1), the region occupied by the southern two turtlebacks (Mormon Point and Copper Canyon) and the adjacent Miocene intrusions (Figure 2). Two samples (988-20 and 988-25) of undeformed 11.6 Ma Willow Spring Pluton collected from the same outcrop near Willow Spring in Gold Valley (Figure 2) give homblende plateau ages of $10.42 \pm 0.31 \mathrm{Ma}$ and $10.16 \pm$ $0.20 \mathrm{Ma}$ and concordant intercept ages of $10.3 \pm 0.2 \mathrm{Ma}$ and $10.2 \pm 0.5 \mathrm{Ma}$. A hornblende separate from another undeformed sample (CCR-AR, collected $\sim 6.4 \mathrm{~km}$ north of this locality) gives a plateau age of $10.06 \pm 0.39 \mathrm{Ma}$ and a concordant intercept age of $9.8 \pm 0.2 \mathrm{Ma}$. Biotite separates from samples 988-20 and 988-25 give concordant total gas, intercept, and plateau ages of $8.36 \pm 0.17 \mathrm{Ma}$ and $8.39 \pm 0.13$ Ma respectively. We interpret these ages as indicating postcrystallization cooling below $500^{\circ} \mathrm{C}$ at $10.25 \pm 0.15 \mathrm{Ma}$ and below $300^{\circ} \mathrm{C}$ at $8.40 \pm 0.15 \mathrm{Ma}$.

Release spectra were also obtained from plagioclase and orthoclase separates from sample 988-20. The Willow Spring Pluton contains only minor amounts of orthoclase and separation from plagioclase was fraught with difficulty owing to the presence of hydrated plagioclase grains. A separate consisting of $\sim 50 \%$ orthoclase and $\sim 50 \%$ plagioclase did not give a plateau but yielded an intercept age of $7.2 \pm 0.3 \mathrm{Ma}$ in agreement with its total gas age. While caution must be used in interpreting such data, it is worth noting that McKenna [1990] obtained an intercept age of $7.03 \pm 0.04 \mathrm{Ma}$ for an orthoclase separate from a nearby granite which intrudes the Willow Spring Pluton. Thus we tentatively interpret these data to indicate cooling below $200^{\circ}-250^{\circ} \mathrm{C}$ (commonly determined closure temperature range from diffusion studies on K-feldspars [e.g., Hubbard and Harrison, 1989]) at 7.0-7.5 Ma.

Two splits of plagioclase from sample 988-20 yielded saddle-shaped spectra. The first split gives a plateau age of $5.89 \pm 0.51 \mathrm{Ma}$ for nine increments consisting of $76 \%$ of the gas and a concordant intercept age of $5.9 \pm 0.4 \mathrm{Ma}$. The second split gives a plateau age of $6.70 \pm 0.61 \mathrm{Ma}$ for eight increments consisting of $70 \%$ of the gas and an intercept age of $6.4 \pm 0.3 \mathrm{Ma}$. The disparate ages for two splits of the same separate as well as the saddle-shaped spectra lead to difficulties in interpreting these data. In addition, the lower discordant age from the orthoclase separate (in spite of a similar or possibly even higher closure temperature based on empirical evidence [McDougall and Harrison, 1988]) indicate to us no appropriate meaningful interpretation.

Intruded into the Willow Spring Pluton in the southern Gold Valley area (and underlying much of Smith Mountain, Figure 2) is a coarse grained granite which commonly exhibits Rapakivi texture and locally contains abundant coarse hornblende grains. A hornblende separate (TPG-SM) gives an intercept age of $8.7 \pm 0.1 \mathrm{Ma}$ and a near plateau for the last 10 increments (78\% of the gas) of $8.5 \pm 0.4 \mathrm{Ma}$ with the oldest increment being $8.72 \pm 0.15 \mathrm{Ma}$. Biotite from this sample gives an intercept age of $8.1 \pm 0.1 \mathrm{Ma}$ and a plateau age of $8.00 \pm 0.21 \mathrm{Ma}$ indicating that the granite cooled quite rapidly. Because the adjacent Willow Spring Pluton into which this granite intruded cooled below $500^{\circ} \mathrm{C}$ at $10.1-10.4 \mathrm{Ma}$, we interpret the $8.7 \mathrm{Ma}$ homblende age as representing the approximate time of crystallization of the intrusion.

A homblende separate (TQM-HB) from a coarse-grained silicic pluton on the east side of the Black Mountains yielded a slightly saddle-shaped spectrum with a plateau age of $10.11 \pm$ 
$0.73 \mathrm{Ma}$. However, the isotope correlation diagram, when regressed through the plateau points, gives an intercept age of 8.7 $\mathrm{Ma}$ and an initial ${ }^{40 \mathrm{Ar}} /{ }^{36} \mathrm{Ar}$ ratio of $312.02 \pm 5.12$ indicating the presence of excess argon. When an initial ${ }^{40} \mathrm{Ar} /{ }^{36} \mathrm{Ar}$ ratio of 312 is assumed for the incremental release spectrum, the saddle shape disappears and the plateau age becomes $8.69 \pm 0.31 \mathrm{Ma}$, concordant with the intercept age. This pluton, like the Smith Mountain Granite, intruded into the Willow Spring Pluton, and its hornblende age is similar to the hornblende age of the Smith Mountain Granite. We interpret this age as representing the time of crystallization of several silicic plutons in the Black Mountains.

Late-stage latite and rhyolite dikes with biotite and feldspar phenocrysts intrude both the Willow Spring Pluton and the Smith Mountain Granite in the vicinity of Gold Valley. These dikes exhibit an intense mylonitic foliation which commonly does not extend into undeformed country rock (Figure 4a). A coarse biotite separate from a dike sample (TPL-BIO) that intrudes the Willow Spring Pluton collected near Willow Spring (Table 1) yielded a plateau age of $7.85 \pm 0.18 \mathrm{Ma}$ and a concordant intercept age of $7.9 \pm 0.1 \mathrm{Ma}$. These ages are only slightly younger than the biotite ages of the Smith Mountain Granite, the upper bound even overlapping in error with the plateau age although not with the intercept age. We interpret the dike age as the time of intrusion and crystallization into country rock with ambient temperatures between $200^{\circ} \mathrm{C}$ and $300^{\circ} \mathrm{C}$ as indicated by the $\mathrm{K}$-feldspar and biotite ages obtained from the surrounding Willow Spring Pluton.

Precambrian basement samples were collected from the Mormon Point (sample 89-MP) and Copper Canyon turtlebacks (sample 89-CC; Figure 2). These rocks contain a coarsely recrystallized metamorphic fabric. Basement from the Mormon Point turtleback (sample 89-MP) gives a hornblende plateau age of $9.94 \pm 0.44 \mathrm{Ma}$ with a concordant intercept age of $9.9 \pm 0.2 \mathrm{Ma}$ similar to the hornblende ages in the Willow Spring Pluton. A concordant plateau and intercept biotite age from this sample indicates simple cooling below $300^{\circ} \mathrm{C}$ at 8.03 $\pm 0.14 \mathrm{Ma}$. Sample 89-CC shows a complicated homblende spectrum with no intercept regression. The spectrum, however, appears very similar to partially reset spectra from other studies where the minimum age corresponds to a known later heating episode [Harrison and McDougall, 1980]. The minimum age for this spectrum $(11.86 \pm 1.57 \mathrm{Ma})$ corresponds with the age of intrusion of the Willow Spring Pluton, and therefore we interpret this spectrum to represent cooling below $500^{\circ} \mathrm{C}$ by at least $14 \mathrm{Ma}$ with partial resetting at $11.6 \mathrm{Ma}$ due to reheating by the gabbro-diorite batholith. Biotite from this sample yields a concordant intercept and plateau age indicating simple cooling below $300^{\circ} \mathrm{C}$ at $6.63 \pm 0.13 \mathrm{Ma}$. The Copper Canyon turtleback data suggest that the basement rocks in this region

Fig. 4. (a) Photomicrograph of mylonitic texture common in porphyritic dikes in the central Black Mountains (sample TPLBIO). Length is $2.0 \mathrm{~mm}$ across. (b) Photomicrograph of late leucocratic phase of the Willow Spring Pluton (sample 88-23) showing quartz in contact with hornblende (curved arrows). Straight arrows point to examples of K-feldspar grains and Kfeldspar inclusions in plagioclase. Length is $0.5 \mathrm{~mm}$ across. (c) Photomicrograph of euhedral homblende crystal from the Smith Mountain Granite (sample TPG-SM) in quartzplagioclase-potassium feldspar-biotite rich matrix. Length is $0.5 \mathrm{~mm}$ across. were below $500^{\circ} \mathrm{C}$ prior to intrusion of the Willow Spring Pluton. We interpret the Mormon Point hornblende age as having been completely thermally reset by the batholith at 11.6 $\mathrm{Ma}$, followed by slow cooling to below $500^{\circ} \mathrm{C}$ at $10 \mathrm{Ma}$ (note the similar hornblende ages from the Willow Spring Pluton).
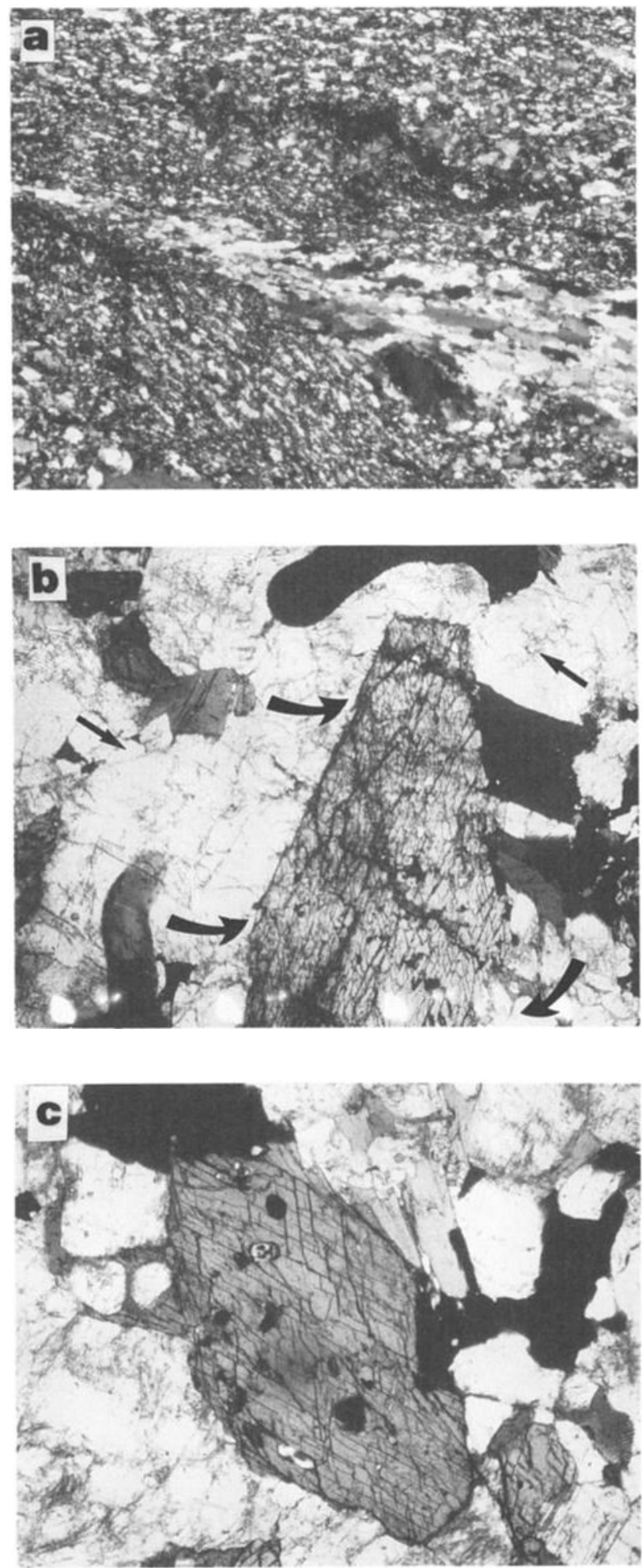
A ductilely deformed sample of the Willow Spring Pluton (sample DH-2650) obtained beneath the foliated Eocambrian carapace on the northeast side of the Copper Canyon turtleback (Figure 2) gives a hornblende plateau age of $8.77 \pm 0.70 \mathrm{Ma}$ with a concordant intercept age of $8.9 \pm 0.6 \mathrm{Ma}$. Biotite from this sample yielded a plateau age of $6.66 \pm 0.12 \mathrm{Ma}$ and an intercept age of $6.8 \pm 0.1 \mathrm{Ma}$. Another deformed gabbro-diorite sample (DH-3780) from a ductile shear zone $\sim 3 \mathrm{~km}$ northwest of sample DH-2650 gives a hornblende plateau age of $8.05 \pm$ $0.28 \mathrm{Ma}$ and an intercept age of $8.3 \pm 0.5 \mathrm{Ma}$. Biotite from this sample does not yield a plateau age but does give an intercept age of $7.0 \pm 0.1 \mathrm{Ma}$. The hornblende ages from these samples are substantially younger than the homblende ages derived from undeformed samples. The batholith intruded at 11.6 Ma into country rock with ambient temperatures below $500^{\circ} \mathrm{C}$ and cooled below $500^{\circ} \mathrm{C}$ at 10.1-10.4 Ma. Therefore we interpret these younger homblende ages associated with ductilely deformed samples as indicating resetting during mylonitization with ambient temperatures between $300^{\circ} \mathrm{C}$ and $500^{\circ} \mathrm{C}$. Davidson and Snee [1990] have demonstrated that under greenschist facies conditions $\left(>300^{\circ} \mathrm{C}\right)$ homblende can be reset during ductile shearing at ambient temperatures below the hornblende closure temperature. Mylonite fabrics are typically formed at temperatures above the closure temperature for diffusion in biotite. We therefore interpret the 6.7 and $7.0 \mathrm{Ma}$ biotite ages from these samples as representing simple cooling following deformation.

The Copper Canyon turtleback is intruded by felsic dikes which are oriented perpendicular to the axis of the turleback fold [Drewes, 1963]. Biotite in these dikes are often extensively altered to chlorite, and commonly exhibit deformation features such as strain shadows and kink bands. A biotite separate from one of these dikes was considered pure enough for age dating only after 2 days of hand-picking. Sample CCTB-B did not yield a plateau age but did give concordant intercept and total gas ages of $6.9 \pm 0.2 \mathrm{Ma}$ and 6.8 $\pm 0.2 \mathrm{Ma}$, respectively. These ages overlap with the biotite cooling ages obtained from the Precambrian basement and the Willow Spring Pluton in this region. The Copper Canyon turtleback dikes are volumetrically small and are considered unlikely to have completely thermally reset the surrounding country rock to above $300^{\circ} \mathrm{C}$. We interpret the $6.9 \pm 0.2 \mathrm{Ma}$ intercept age as the time of intrusion of these dikes into rapidly cooling country rock similar to dike intrusion in the Gold Valley region $\sim 1.0$ m.y. earlier.

Northern Black Mountains. Samples BWT-B and DHBWT-2 are mylonitized Precambrian basement from the Badwater turtleback in the northern Black Mountains. Sample BWT-B is located only a few meters below the brittle detachment surface, whereas sample DH-BWT-2 was collected from a deeply incised canyon in the lower plate (approximately $200 \mathrm{~m}$ below the brittle detachment surface). Micas from both localities are strained into mica-fish profiles typical of mylonitic textures. Muscovite from sample DH-BWT-2 shows a typical diffusion loss profile with an age minimum of $16.03 \pm 1.90 \mathrm{Ma}$, four increments (representing $72 \%$ of the gas) with ages between 23.4 and $24.4 \mathrm{Ma}$, and an intercept age of $24.0 \pm 0.4 \mathrm{Ma}$. Biotite from sample DH-BWT-2 is strongly discordant from the muscovite age giving a concordant intercept and plateau age of $12.63 \pm 0.50 \mathrm{Ma}$. Biotite from sample BWT-B gives a slightly older plateau age of $13.23 \pm$ $0.23 \mathrm{Ma}$ and a concordant intercept age of $13.4 \pm 0.1 \mathrm{Ma}$. We interpret these data as indicating that the Badwater turtleback basement rocks cooled slowly through the $350^{\circ} \mathrm{C}$ isotherm at $\sim 24$ Ma with further cooling through $300^{\circ} \mathrm{C}$ at $\sim 13 \mathrm{Ma}$.

Fine-grained dioritic dikes cut the basement foliation at a high angle and are synkinematic with late-stage brittle faulting [Miller, 1991]. A whole rock analysis of one of these dikes (sample 90-38) gives a plateau age and concordant intercept age that indicates crystallization at $6.3 \pm 0.2 \mathrm{Ma}$. These data suggest that the basement rocks of the Badwater turtleback were within a few kilometers of the Earth's surface by at least 6.3 Ma.

Greenwater Range. The Greenwater Range lies just east of the Black Mountains (Figures 1 and 2) and consists of Tertiary silicic plutons overlain by $10-4$ Ma variably faulted mafic to silicic volcanic rocks. In the southern Greenwater Range, 8-9 Ma Shoshone volcanics lie depositionally on feldspar porphyry granite [Figure 2; L. Wright and B. Troxel, personal communication]. A biotite separate from this granite (sample TQM-GW-B) gave concordant total gas, intercept, and plateau ages of $9.76 \pm 0.25 \mathrm{Ma}$, consistent with rapid cooling from above $300^{\circ} \mathrm{C}$ at $9-10 \mathrm{Ma}$. This age is approximately $1 \mathrm{~m} . \mathrm{y}$. older than the age interpreted for major silicic plutonism in the central Black Mountains.

\section{GEOBAROMETRY RESULTS}

A lower bound on the depth estimate for crystallization of the Willow Spring Pluton at $9.5-12.5 \mathrm{~km}$ was determined by Holm and Wernicke [1990, Table 1] using the $\mathrm{Al}$-in-hornblende geobarometer [Hammarstrom and Zen, 1986; Johnson and Rutherford, 1989] and assuming an overburden density of 2750 $\mathrm{kg} / \mathrm{m}^{3}$. As observed by Holm and Wernicke [1990] and corroborated by Wright et al. [1991] the main portion of the batholith does not contain the appropriate assemblage required for this geobarometer. However, late leucocratic portions of which are intrusive into the main portion do contain the required assemblage. We concur with Wright et al. [1991] that their samples were inappropriate for using this geobarometer as they were unable to find any potassium feldspar and could not locate quartz in contact with hornblende. However, samples analyzed by Holm and Wemicke [1990] do contain potassium feldspar (as evidenced from optical, microprobe, and chemical staining analyses) as well as quartz in contact with homblende (Figure 4b). In addition, successful analyses and similar results using this geobarometer on these rocks have been reported by Meurer and Pavlis [1991].

Dated samples of the Smith Mountain Granite (TPG-SM) also contain the proper mineral assemblage necessary for application of the Al-in-homblende geobarometer. The results of microprobe analyses of coarse euhedral hornblendes (Figure 4c) from three doubly polished sections of the granite are given in Table 2. Total Al content from rim analyses of homblende indicates a pressure of $2.76 \pm 0.5 \mathrm{kbar}$ (using the modified equation of Johnson and Rutherford [1989, p. 838]) or a depth estimate of $10.0 \pm 1.8 \mathrm{~km}$ using an average overburden density of $2750 \mathrm{~kg} / \mathrm{m}^{3}$. The total Al content obtained here is substantially greater than that recently reported for the Smith Mountain Granite by Wright et al. [1991]. A possible explanation for this discrepancy might be that different phases of the granite were sampled. Considering that intrusion occurred simultaneously with unroofing, it seems quite possible that various phases might record different depths of emplacement. 
TABLE 2. Cation Proportions From Rim Analyses of Hornblende in Smith Mountain Granite

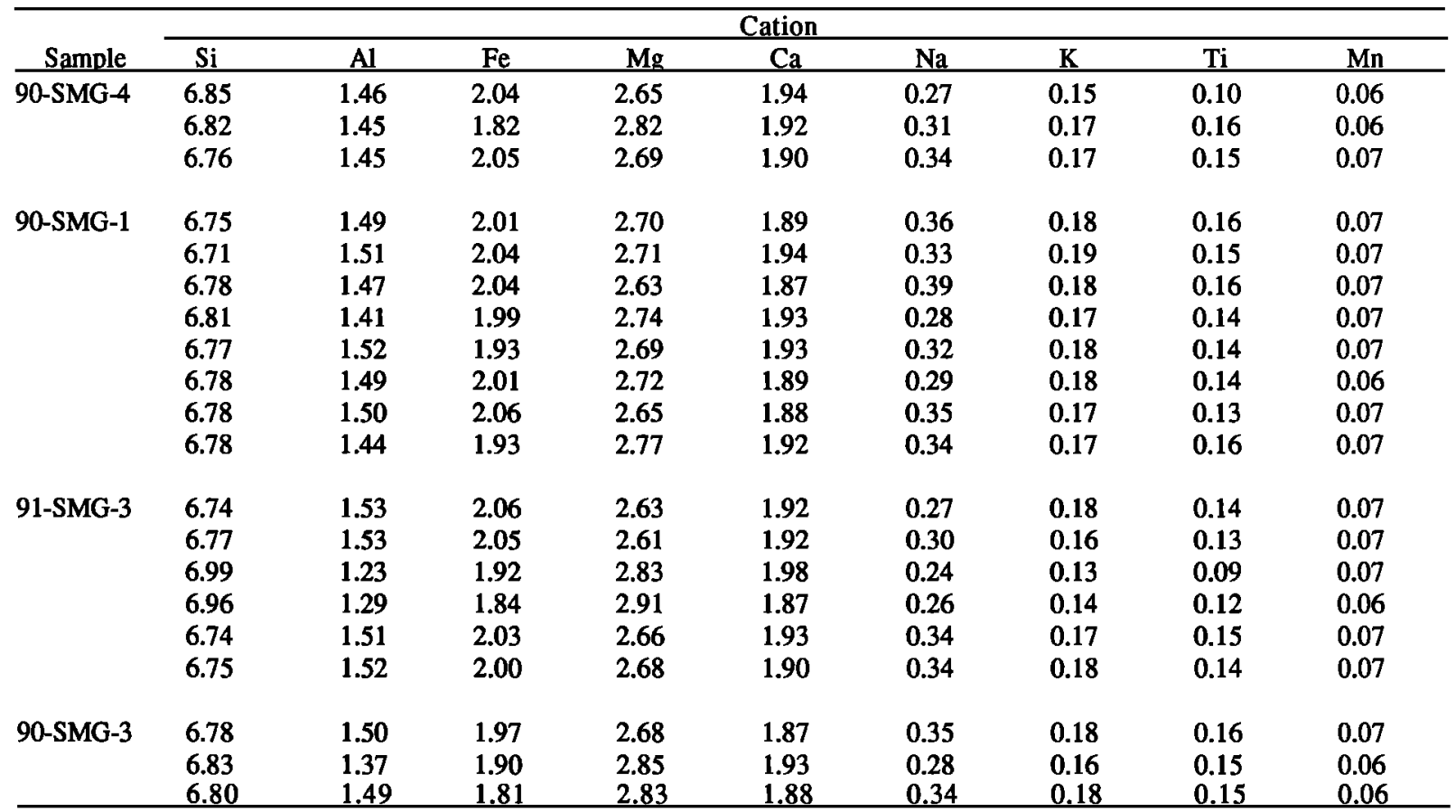

Proportions are per 23 oxygens.

\section{DISCUSSION}

Timing, Depth, and Deformation of Miocene Intrusions

Intrusions in the Black Mountains are entirely Tertiary in age, the oldest being the Willow Spring Pluton dated at 11.6 \pm $0.2 \mathrm{Ma}$ [Asmerom et al., 1990]. Previous mapping distinguished at least three major silicic intrusive bodies younger than the pluton based on compositional differences and dike relations [Drewes, 1963; Otton, 1977].

Willow Spring Pluton. The minimum hornblende age of $\sim 14.3$ Ma for a thermally reset Precambrian basement sample (89-CC) in the central Black Mountains indicates ambient temperatures below $500^{\circ} \mathrm{C}$ prior to intrusion of Tertiary plutons. This establishes an upper bound for the depth of intrusion of the Willow Spring Pluton at $\sim 16.7-20 \mathrm{~km}$ assuming typical Basin and Range geothermal gradients after Lachenbruch and Sass [1978] of $25-30^{\circ} \mathrm{C} / \mathrm{km}$ prior to intrusion. Considering elevated geothermal gradients during Miocene time would make the upper bound for intrusion depth even less. The 8.4-6.7 Ma biotite ages from the pluton (samples 988-20, 988-25, DH-2650, and DH-3780) are too young to be attributed to simple postemplacement conductive cooling of an $11.6 \mathrm{Ma}$ intrusion. We therefore interpret the biotite ages as representing cooling associated with extensional unroofing. This interpretation implies that the pluton intruded into country rock with ambient temperatures above $300^{\circ} \mathrm{C}$. Again, assuming $25-30^{\circ} \mathrm{C} / \mathrm{km}$ geothermal gradients, we obtain a lower bound for intrusion emplacement depth of $10-12 \mathrm{~km}$. This lower bound is consistent with geobarometric results on a late crystallization phase of the pluton. Allowing for some uplift between crystallization of the main and late leucocratic phases of the pluton, considering it crystallized and cooled during regional extensional tectonism and unroofing in the Death Valley region [Cemen et al., 1985; Holm and Dokka, 1991], we consider an intrusion depth for the main phase of the pluton of 10-15 km most likely.

The Death Valley turtlebacks contain a thick, welldeveloped mylonitic foliation in basement rocks that is subparallel to the overlying carbonate carapace and brittle detachment surface. Involvement of foliated and lineated Willow Spring Pluton in these footwall mylonites (sample DH-2650) indicates that at least some of the foliation formed during Miocene extension [Holm and Wernicke, 1989; Holm and Lux, 1991]. Mylonitic deformation appears to have begun prior to intrusion of the Smith Mountain Granite complex as suggested by the $\sim 8.9$ Ma hornblende age from deformed gabbro-diorite (sample DH-2650), consistent with the observation that the Willow Spring Pluton is more ductilely deformed than the younger granitic complex [Holm and Wernicke, 1990].

Smith Mountain Granite complex. The 8.7 Ma hornblende ages obtained from granitic plutons in the central Black Mountains (samples TQM-HB and TPG-SM) signify a major silicic intrusive event coeval with extensive volcanism in the Greenwater range. The Smith Mountain Granite and coeval plutons in the central Black Mountains intruded into country rock with an ambient temperature above $300^{\circ} \mathrm{C}$ as indicated by the 8.4 Ma biotite ages obtained from the Willow Spring Pluton country rock into which it intruded. We interpret the 8.2 Ma biotite age obtained from the Smith Mountain Granite as indicating continued postemplacement cooling after the country rock had cooled through $300^{\circ} \mathrm{C}$. The ${ }^{40} \mathrm{Ar} /{ }^{39} \mathrm{Ar}$ cooling age data and geobarometry on the Smith Mountain Granite, taken together, are consistent with a depth range for crystallization of $8.2-11.8 \mathrm{~km}$. 

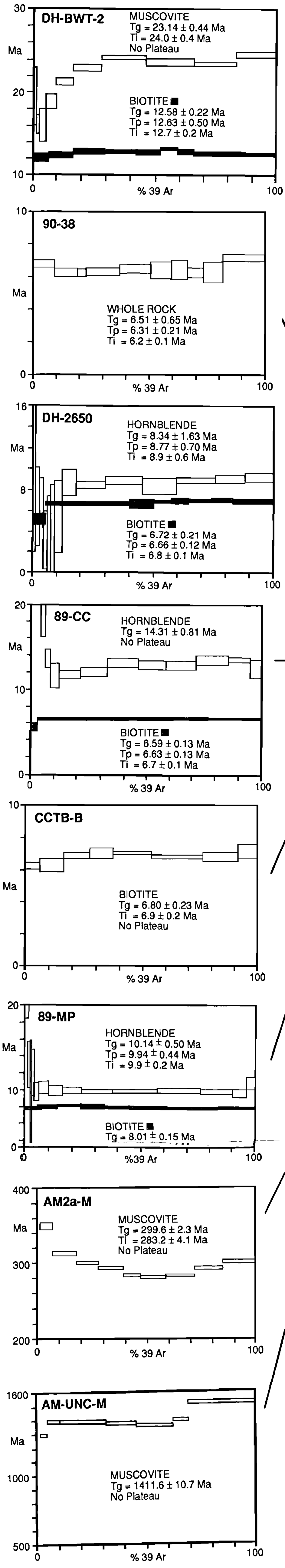
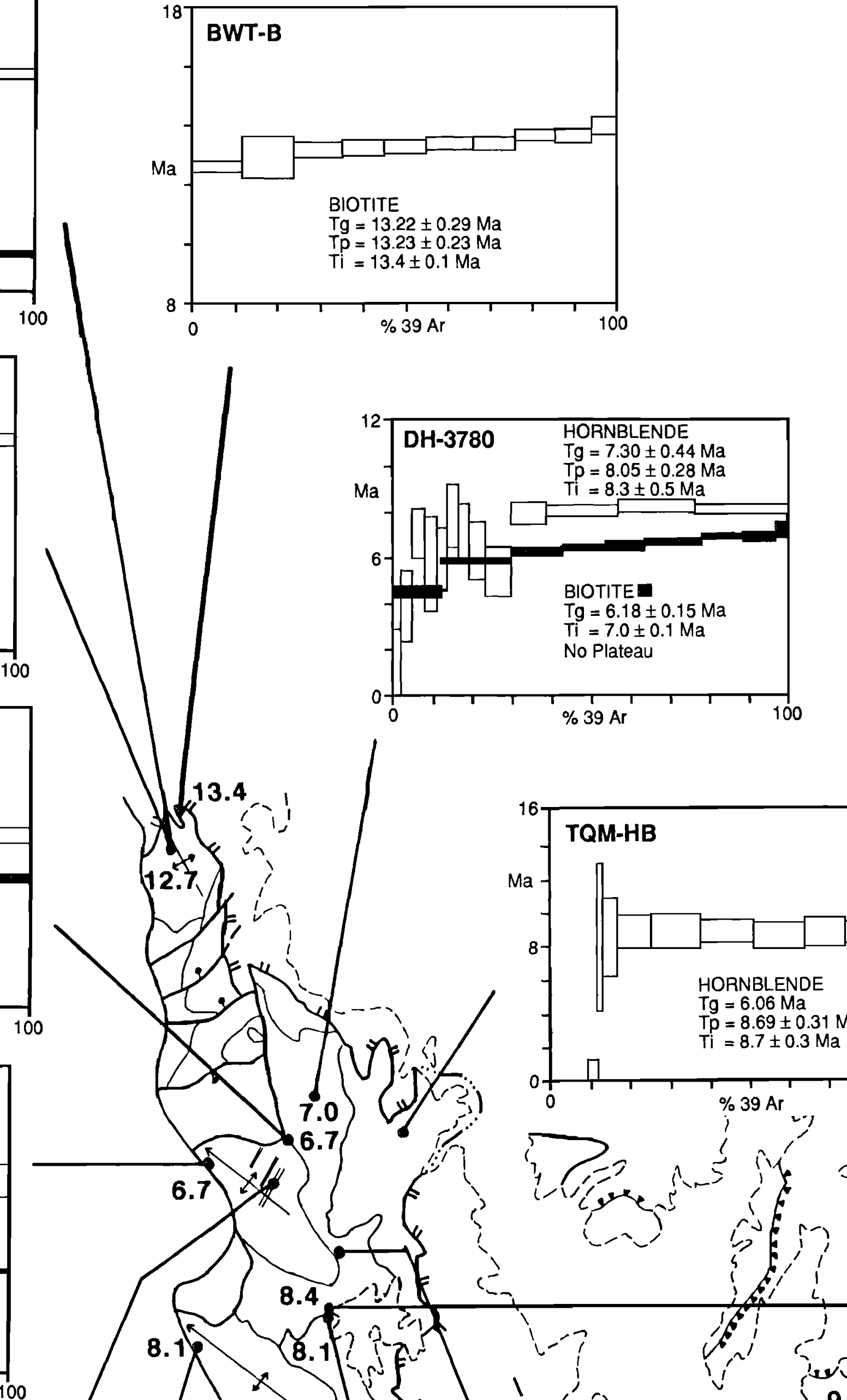

7.0
6.7
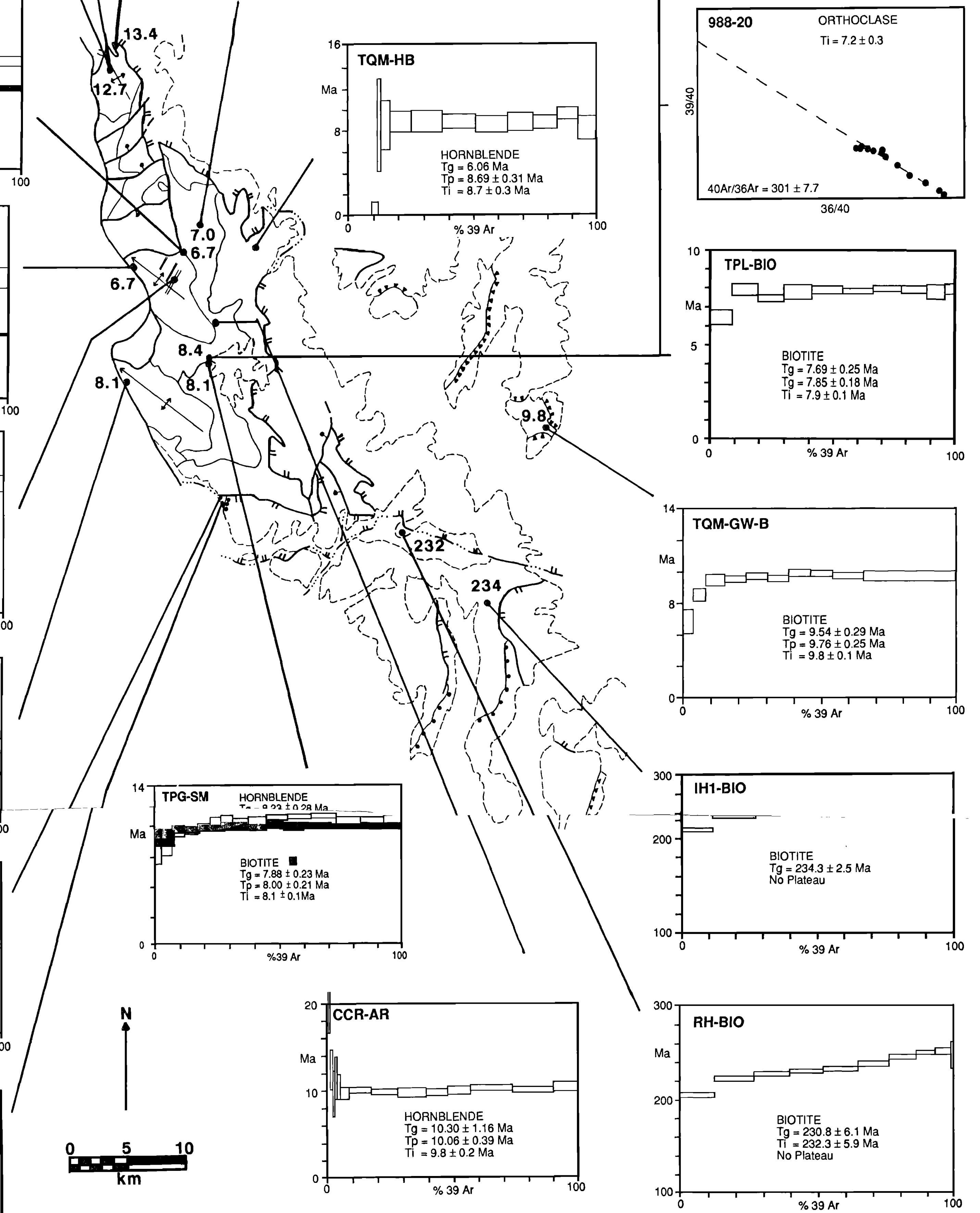

Plate 1. The ${ }^{40} \mathrm{Ar}{ }^{39} \mathrm{Ar}$ age spectra and intercept diagram of dated minerals and rocks with sample

localities plotted on the geologic map from Figure 2 (unpatterned here). Numbers adjacent to some localities are ages (in millions of years) plotted for ease of viewing the overall cooling age pattern for
biotite. 
Greenwater plutons. Granitic plutons in the adjacent Greenwater range (Figure 1) are depositionally overlain by 8-9 $\mathrm{Ma}$ Shoshone volcanics and yield a biotite plateau age of 9.76 $\pm 0.25 \mathrm{Ma}$, substantially older than both the hornblende and biotite ages from the Smith Mountain Granite complex. Because field relations indicate that all silicic intrusions in the Black Mountains are younger than the Willow Spring Pluton [Drewes, 1963], we infer that the Greenwater plutons represent crystallization of a granitic body intemediate in age between the Willow Spring Pluton and the Smith Mountain Granite complex. Although no basement rocks are exposed in the vicinity of this pluton, we note that it appears to be located in the same structural position or depth beneath the late Precambrian nonconformity and overlying Miocene volcanic rocks as the basement rocks in the southeastern Black Mountains. It seems likely therefore that this pluton intruded at shallow levels into country rock colder than $300^{\circ} \mathrm{C}$ and that the 9.76 Ma biotite age represents a near crystallization age. The nearly concordant age of the overlying Shoshone volcanics indicates unroofing and exposure prior to $9 \mathrm{Ma}$, soon after crystallization.

Mylonitic dikes. Numerous porphyritic latite and rhyolite dikes in the central Black Mountains commonly exhibit a mylonitic foliation which is usually (although not always) absent in the country rock adjacent to these dikes. A $7.85 \mathrm{Ma}$ biotite age obtained from a dike near Willow Spring in Gold Valley indicates crystallization of these dikes within $1.0 \mathrm{~m} . \mathrm{y}$. after crystallization of the Smith Mountain Granite complex. The dike nature and the porphyritic texture of these late-stage intrusions indicate colder ambient temperatures and therefore likely a shallower depth of intrusion than the older plutonic complex. At Gold Valley, these dikes intruded into country rock undergoing rapid cooling rates of $35^{\circ}-100^{\circ} \mathrm{C} / \mathrm{m}$.y. based on the age and closure temperature differences between biotite and $\mathrm{K}$-feldspar. We interpret dike intrusion as fracture infilling of crust brittlely deforming during rapid unroofing. Because the temperature of the dikes would be substantially higher than the surrounding country rock immediately after emplacement, these dikes deformed ductilely in an overall brittle regime, thus having a mylonitic foliation imparted to them which is largely nonexistent in the adjacent country rock.

Thermochronologic data from Tertiary plutons, combined with geobarometric data, provide time-depth constraints on the Miocene intrusive history of the Black Mountains crystalline terrain. At 11.6 Ma, the Willow Spring Pluton intruded at a depth range of $10-15 \mathrm{~km}$ into country rock with an ambient temperature below $500^{\circ} \mathrm{C}$. At $\sim 8.7$ Ma the Smith Mountain Granite complex intruded at a depth of $8.2-11.8 \mathrm{~km}$ into country rock with temperatures above $300^{\circ} \mathrm{C}$. These time and depth constraints indicate only minor to moderate amounts of unroofing $(0-6.8 \mathrm{~km})$ at average rates of $0-2.2 \mathrm{~mm} / \mathrm{yr}$ between 11.6 Ma and 8.7 Ma. Clasts of both the Smith Mountain Granite complex and the Willow Spring Pluton in the Copper Canyon Formation to the north [Holm and Lux, 1991] indicate exposure of these rocks prior to $5 \mathrm{Ma}$. Thus data from the Gold Valley area indicate an increase of unroofing rates to greater than $2.3-3.2 \mathrm{~mm} / \mathrm{yr}$ after $8.7 \mathrm{Ma}$.

\section{Translation of the Amargosa Chaos}

Holm and Wernicke [1990] observed that the crystalline rocks in the central Black Mountains lie well away from Tertiary unconformities of pre-10 Ma strata which lie exclusively on unmetamorphosed strata of Paleozoic, Eocambrian, or late Precambrian age, suggesting significant preextensional depths. One exception is the area occupied by the Amargosa chaos at the vicinity of Ashford Canyon south of the Mormon Point turtleback (Figure 2). Here late Precambrian Pahrump Group strata and overlying Tertiary strata are deposited on basement which cooled below $350^{\circ} \mathrm{C}$ at approximately $1380 \mathrm{Ma}$ (sample AM-UNC-M). These rocks lie only 5-6 km south of exposures of the Willow Spring Pluton and the regionally metamorphosed Noonday Dolomite on the Mormon Point turtleback (Figure 3). This area occupies the southern boundary of the Nopah Upland (Figure 5), described as a region of crystalline rock uplifted in the late Precambrian (pre-Noonday time) and flanked to the south by Pahrump Group strata [Wright et al., 1974b]. At Ashford Canyon and elsewhere, unmetamorphosed Pahrump Group strata lie only $2-3 \mathrm{~km}$ below the Tertiary unconformity, implying shallow depths at the onset of extension. Wright and Troxel [1984] have argued that the relative positions of
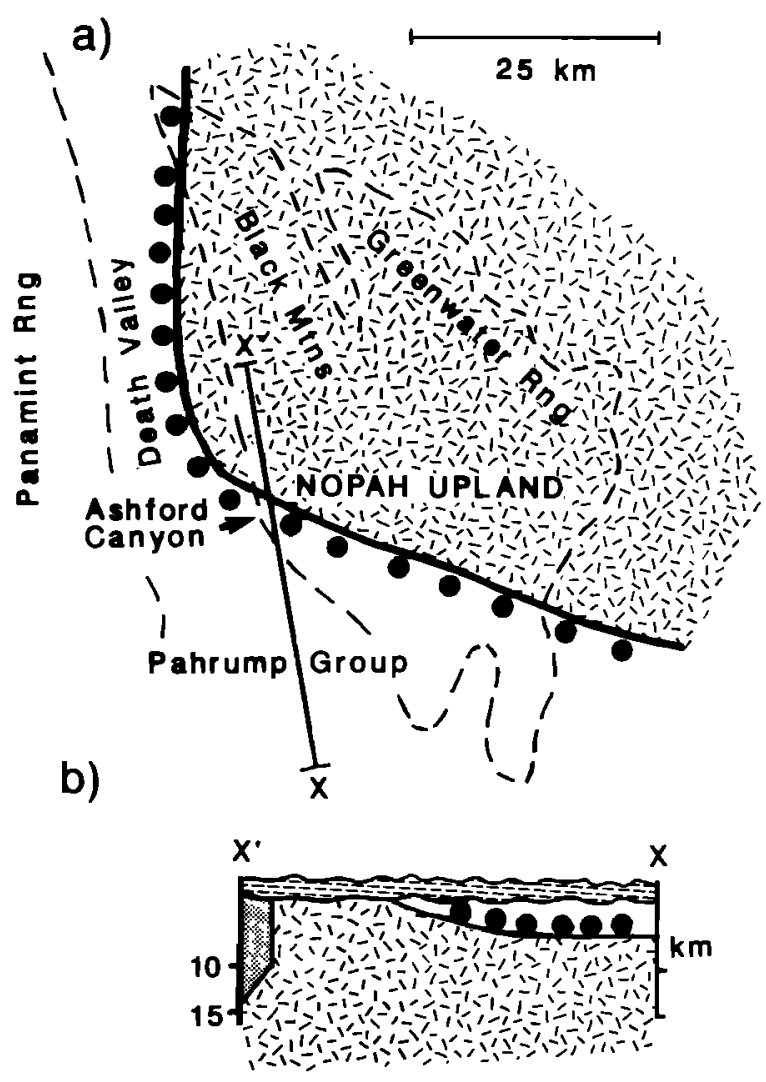

Fig. 5. (a) Paleogeologic map of the Death Valley region, representing time that immediately preceeded deposition of the Noonday Dolomite [after Wright et al., 1974b]. Filled circles represent basal nonconformity of Pahrump Group strata. (b) Cross section $\mathrm{X}-\mathrm{X}$ ' just prior to Tertiary volcanism showing the shallow depth required for the Nopah Upland assuming stratigraphic depth equals structural depth. Dashed lines represent late Precambrian strata. Shaded region depicts the "missing" depth differential (7-13 km) considering that the 11.6 Ma Willow Spring Pluton intruded at a depth of 10-15 $\mathrm{km}$. See text for discussion. 
basement rocks and various Pahrump Group sections in this area have remained intact since Precambrian time. If it is assumed that stratigraphic depth equals structural depth, the paleogeography according to Wright et al. [1974b] would require the Precambrian basement rocks making up the Mormon Point and Copper Canyon turtleback to lie only a few kilometers below the surface at the onset of extension (Figure 5). However, the ${ }^{40} \mathrm{Ar} /{ }^{39} \mathrm{Ar}$ data and geobarometry on Miocene intrusions presented here indicate a midcrustal depth $(10-15 \mathrm{~km})$ for these rocks during Miocene time.

It seems unlikely that Miocene intrusive rocks beneath the Precambrian nonconformity at Ashford Canyon could have a differential depth of 7-13 km over a distance of only 5-6 km between their exposure along the Mormon Point turtleback and Ashford Canyon (Figure 3). Holm and Wernicke [1990] attributed the proximity of the unmetamorphosed and regionally metamorphosed Pahrump Group strata to translation of the unmetamorphosed rocks northwestward away from an original position in the southeastern Black Mountains. Translation occurred along a detachment zone underlying the highly faulted Amargosa chaos, the detachment zone having locally cut into basement rocks beneath the nonconformity, thus juxtaposing allochthonous basement (and the overlying nonconformity) onto intact basement in the vicinity of Ashford Canyon (Figure 3). We emphasize that this detachment fault would be difficult to map where basement was faulted onto basement. However, the $\sim 283$ Ma muscovite age minimum of sample AM2a-M approaches ages obtained from the basement in the southeastern Black Mountains (samples RH-BIO and IH1-BIO) suggesting equivalence. In addition, this sample, collected nearer to the inferred fault than sample AM-UNC-M, shows a disturbed spectra with excess ${ }^{40} \mathrm{Ar}$, a characteristic common in faulted and sheared rocks. We conclude that the thermochronologic data presented here, when taken in conjuction with depth determinations for Miocene intrusions, are best explained by restoration of the Amargosa chaos (and the late Precambrian nonconformity exposed at Ashford Canyon) 15-20 km southeastward to equivalent rocks in the southeastem Black Mountains.

\section{Cooling Age Pattern}

Samples from the southeastern and central Black Mountains show a pattern of cooling with biotite ages younging toward the northwest (Plate 1). Biotite total gas ages of $230-235 \mathrm{Ma}$ from Precambrian basement in the southern Black Mountains (samples RH-BIO and IHI-BIO) suggest temperatures below $300^{\circ} \mathrm{C}$ well before the onset of extension in this region. Shallow depths for these rocks prior to Tertiary unroofing would be expected given their proximity to unmetamorphosed late Precambrian-Cambrian and Tertiary sedimentary rocks which depositionally overlie basement in the southeastern Black Mountains. Taking $300^{\circ} \mathrm{C}$ as the maximum temperature of these samples prior to Tertiary unroofing and considering a low geothermal gradient, we obtain a depth maximum of 12 $\mathrm{km}$ prior to extension. Thermochronology and field relations in the adjacent Greenwater Range indicate unroofing of $\sim 10 \mathrm{Ma}$ shallow level granites between 9 and 10 Ma while the western Black Mountain rocks remained deeper than $10 \mathrm{~km}$.

In the central Black Mountains, biotite ages within the Willow Spring Pluton show a younging towards the northwest with samples collected from Gold Valley cooling through $300^{\circ} \mathrm{C} \sim 1.5 \mathrm{~m}$.y. before samples collected at and northeast of the Copper Canyon turtleback. This cooling age pattern is visible in samples from both the pluton and the Precambrian basement rocks suggesting that the pluton thermally equilibrated with the country rock at temperatures above the closure temperature for biotite. We interpret the northwest younging of biotite cooling ages to reflect progressive tectonic unroofing of the Copper Canyon and Mormon Point turtlebacks toward the northwest from midcrustal depths (temperatures above $300^{\circ} \mathrm{C}$ ), consistent with the overall regional extension direction and with regional west directed tectonic denudation suggested by Wright et al. [1984]. Progressive unroofing was accompanied by footwall dike intrusion which also decrease in age toward the northwest.

Mica cooling ages from the northern Black Mountains (the Badwater turtleback) are substantially older than micas from both the Copper Canyon and Morman Point turtlebacks in the central Black Mountains. The dissimilar cooling ages suggest that rocks making up the Badwater turtleback lay at a shallower level in the crust prior to intrusion of the Willow Spring Pluton and the onset of unroofing than were the rocks of the Copper Canyon and Mormon Point turtlebacks. Therefore the Copper Canyon and Mormon Point turtlebacks would represent the deepest exposed level of the Black Mountains crust unroofed during Tertiary extension; this is in contradiction to the westward deepening crustal section hypothesis presented by Holm and Wernicke [1990]. A possible explanation for the older mica ages which would resolve this contradiction considers the Badwater turtleback as allochthonous with respect to the southern two turtlebacks, having been translated northwestward in the direction of overall regional extension similar to the Amargosa chaos described above. Restoration of the Badwater turtleback southeastward to a location either above or southeast of the Copper Canyon turtleback would account for the correct positioning of older mica ages and would also explain the formation and concentration of high-temperature ductile deformation fabrics around the Copper Canyon turtleback 4-5 m.y. after the Badwater turtleback cooled below $300^{\circ} \mathrm{C}$. Altematively, the northwest dipping detachment fault may have ramped up to a shallower level in the crust toward the northeast in the vicinity of the Badwater turtleback. As dike intrusion seems to have accompanied unroofing and cooling in the Gold Valley and Copper Canyon turtleback regions at 7.9 Ma and 6.8 Ma, respectively, the younger dikes located on the Badwater turtleback (6.3 Ma) may reflect the later unroofing of that area albeit from shallower depths $\left(<300^{\circ} \mathrm{C}\right)$.

\section{Cooling Age versus Elevation}

Hormblende ages from undeformed Willow Spring Pluton samples suggest uniform cooling of the intrusion below $500^{\circ} \mathrm{C}$ at 10.1-10.4 Ma, approximately 1.0 to $1.5 \mathrm{~m} . \mathrm{y}$. after crystallization. Similar hornblende cooling ages from undeformed samples of the pluton were obtained by McKenna [1990]. There is no discemable age difference between samples collected over an elevation difference of $\sim 1.5 \mathrm{~km}$ (Figure 6). This is perhaps not surprising considering that the pluton intruded into country rock with temperatures below $500^{\circ} \mathrm{C}$ at its base. Intrusion of the pluton would have created a temporary unslable geotherm with an inverted isotherm at its base. While it is certainly possible that some cooling might be attributed to denudation, we feel that at these high temperatures cooling was probably dominated by conductive cooling of the pluton as it thermally equilibrated with the country rock. Rapid 


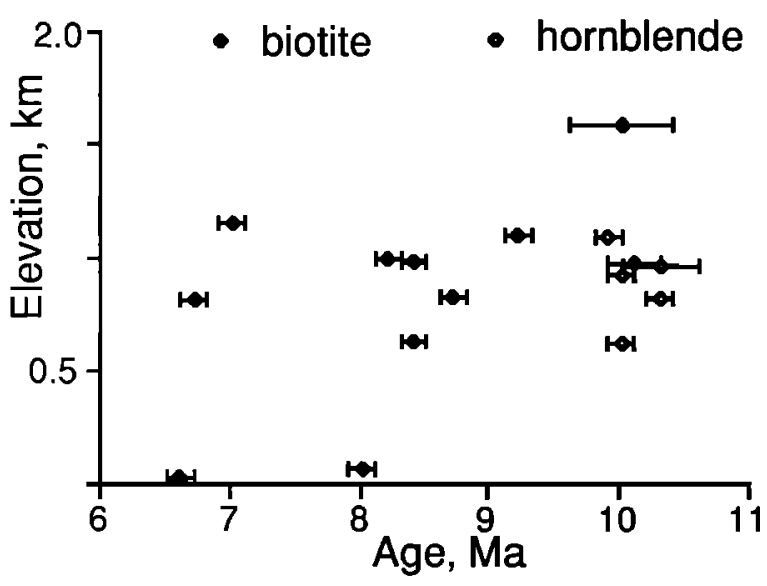

Fig. 6. Cooling age versus elevation data from the central Black Mountains. Data points are from this study and from McKenna [1990]. Hornblende ages are from the Willow Spring Pluton only. Biotite ages are from the pluton and from Precambrian basement.

equilibration of a steep or inverted geotherm cooling through $500^{\circ} \mathrm{C}$ would likely mask any competing effect of cooling associated with vertical denudation and therefore no difference in homblende cooling ages with elevation would be expected [cf. Wright et al., 1991; McKenna and Snee, 1991].

We have also plotted biotite cooling ages (from both Precambrian and gabbro-diorite samples from the central Black Mountains) versus sample elevation using data from this study and from that of McKenna [1990]. At first sight there appears to be considerable scatter in the biotite data with respect to elevation (Figure 6). However, cooling ages obtained from specific regions (8-9 Ma ages from the Gold Valley/Mormon Point area, and 6.7-7.0 Ma ages from the Copper Canyon region) appear to show a steep positive correlation with elevation. A possible interpretation is that the steep slopes represent locally a vertical component of motion (present day coordinates) of the $300^{\circ} \mathrm{C}$ isotherm. If the motion were approximately vertical and related to unroofing, the age versus elevation data from this study suggests unroofing rates of $\sim 2.5$ $4.0 \mathrm{~km} / \mathrm{m} . y$. We emphasize, however, that caution must be used when interpreting such data in the Black Mountains especially considering the recent evidence for Miocene and younger folding of the pluton [Holm and Lux, 1990; Pavlis, 1991].

\section{Initial Dip and Kinematics of Detachment Faulting}

A principal focus of interest in continental extension concerns the initial geometry and angle of dip of major detachment zones [Buck, 1988; Wernicke and Axen, 1988; King and Ellis, 1990; Miller, 1991; Holm, 1991]. The thermochronologic and geobarometric constraints presented here suggest limits on the average initial dip of the Black Mountains detachment. The data presented above indicale that the deepest portions of the Black Mountains (the region adjacent to and occupying the northern portion of the Copper Canyon turtleback) were at a maximum depth of $15 \mathrm{~km}$ prior to the onset of unroofing. Projected onto a cross section subparallel to the regional extension direction these rocks currently lie $-45 \mathrm{~km}$ away from the tilted nonconformity in the southeastern Black Mountains. The current width of exposed footwall relative to changes in structural depth across strike allow an estimate of the average initial dip when variables such as amount of internal extension and amount of overburden are considered. For instance, a thick section of overburden will give a lower estimate for the initial dip of the detachment beneath the nonconformity. Also, internal extension of the range block would cause the current width of exposed footwall to be greater than it initially was and thus make the dip estimate lower. Assuming only 1-2 km of overburden above the nonconformity and a liberal estimate of $50 \%$ internal extension of the range block, we obtain a maximum average initial dip angle of $\sim 30^{\circ}$. Considering $3-5 \mathrm{~km}$ of overburden and less internal disruption (10-20\%) gives initial average angles of $\sim 15^{\circ}-20^{\circ}$. By using this and other techniques, similar average initial dips have also been determined for detachment faults in west central Arizona and southeastem California [Dokka and Baksi, 1988; Miller and John, 1988; Foster et al., 1990; Richard et al., 1990].

Recent mapping of the Badwater turtleback suggests that transport of the upper plate occurred on moderately to steeply dipping surfaces in the middle and upper crust, favoring only moderate amounts of extension in the Death Valley region [Miller, 1991]. In addition, the Black Mountains have been cited as an example of large footwall uplift beneath a planar high-angle normal fault, again requiring only moderate to minor horizontal extension [King and Ellis, 1990]. These conclusions conflict with regional interpretations that suggest large amounts of extension in the region [Snow and Wemicke, 1989; Stewart, 1983; Wernicke et al., 1988] and with the low average initial dip of the detachment obtained here. The conflicting results of the above studies may be resolved in part by considering the initial geometry of the detachment and its evolution during extension. It seems apparent that near the preextensional surface in the southeastern Black Mountains the detachment initially dipped moderately to steeply, as indicated by the moderately to steeply east tilted Tertiary strata and steep fault-bed angles. Considering initial dips in the upper $5-10 \mathrm{~km}$ of $40^{\circ}-90^{\circ}$, the average initial dip below that depth would be of the order of $6^{\circ}-13^{\circ}$ (Figure 7a). These considerations imply an initially listric geometry similar to that commonly observed on reflection seismograms of normal faults in the Basin and Range and elsewhere [Smith and Bruhn, 1984].

As extension and unloading of the footwall occurs, isostatic forces cause the footwall to flex and uplift; this results in the migration of a monoclinal flexure through the footwall in the direction of transport [Hamilton, 1988; Buck, 1988; Wemicke and Axen, 1988]. This would be reflected in a diachronous rapid cooling pattern, a result of unroofing occurring progressively across the range. The differential cooling represented in the ${ }^{40} \mathrm{Ar} /{ }^{39} \mathrm{Ar}$ data, as well as the accompanying footwall dike intrusion in the Black Mountains, may reflect this process. Another consequence would be that gently dipping to subhorizontal ductile fabrics developed in the middle crust (where the average initial angle was very low) during extension would steepen in the brittle upper crust during unloading (Figure 7b). As unroofing continued and the steepened fabrics were brought nearer the surface, they would be tilted once again to lower angles as the flexure continued to migrate through the upper crust. Therefore the high-angle orientation would not be the original orientation as argued by Miller [1991]; rather it is the result of an earlier steepening as the rocks were unroofed from an originally low-angle orientation in the midcrust (Figure 7). 

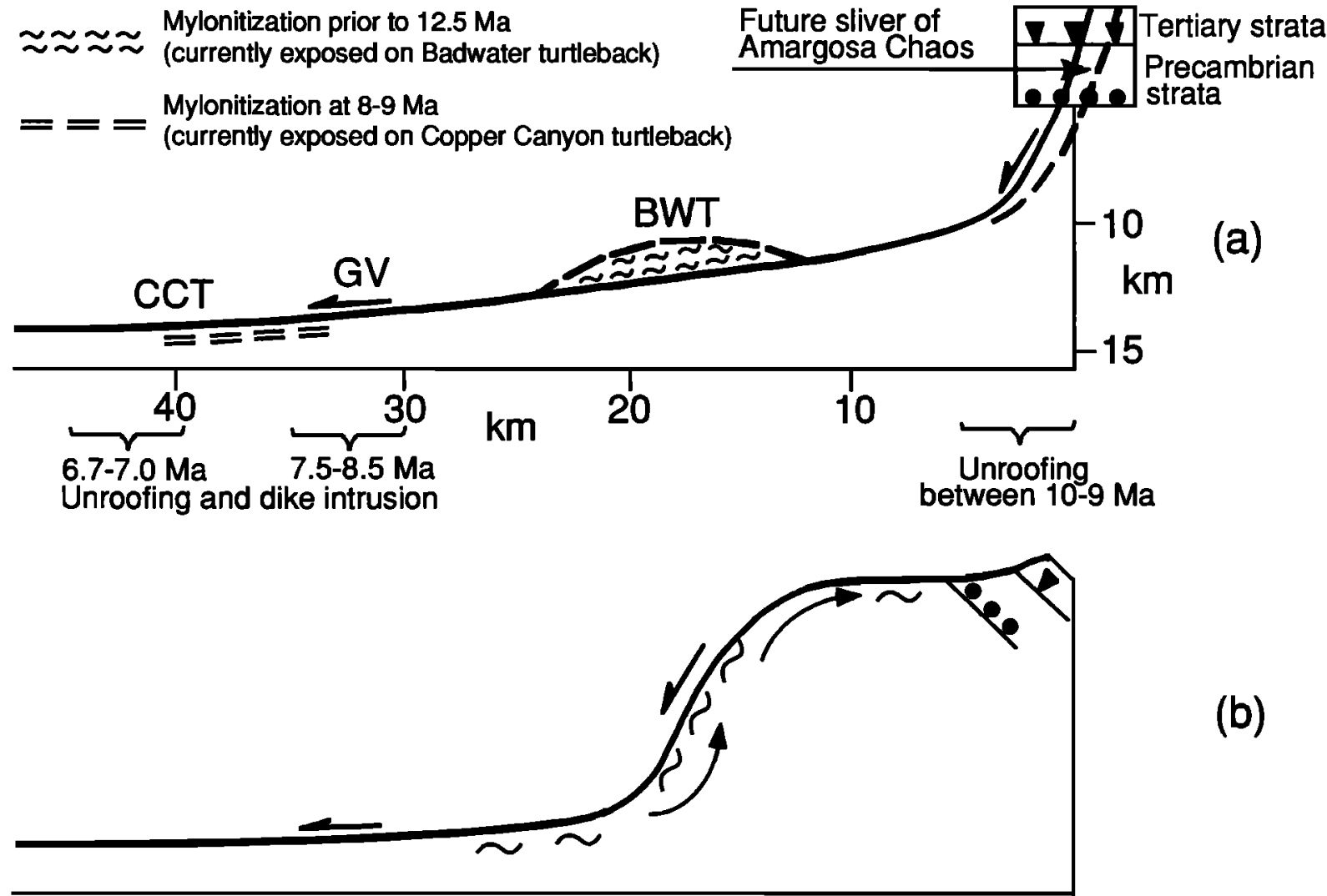

Fig. 7. (a) Schematic cross section (along A-A' of Figure 2) showing likely average initial dip and geometry of detachment fault responsible for unroofing of the Black Mountains and reconstructed position of Badwater turtleback rocks (BWT) prior to unroofing. GV is Gold Valley region; CCT is Copper Canyon turtleback rocks. Depth estimates are obtained from geobarometry and from thermochronology. (b) Diagrammatic representation of preferred model for unroofing of the Black Mountains [after Hamilton, 1988; Buck, 1988; and Wernicke and Axen, 1988]. See text for discussion.

\section{CONCLUSIONS}

We have used ${ }^{40} \mathrm{Ar} /{ }^{39} \mathrm{Ar}$ age spectrum data, combined with geobarometry, to constrain the intrusion and unroofing history of the Black Mountains. Data from the Gold Valley region of the central Black Mountains indicate intrusion of the $11.6 \mathrm{Ma}$ Willow Spring Pluton into country rock with temperatures below $500^{\circ} \mathrm{C}$ and at depths of $10-15 \mathrm{~km}$. A granitic complex dated at $8.7 \mathrm{Ma}$ intruded into country rock above $300^{\circ} \mathrm{C}$ at 8.2 $11.8 \mathrm{~km}$ depths. Intrusion of fine-grained porphyritic latite dikes indicate shallow crustal levels by $7.9 \mathrm{Ma}$. These cooling depth data suggest slow to moderate unroofing rates (0-2.2 $\mathrm{mm} / \mathrm{yr}$ ) between 11.6 and $8.7 \mathrm{Ma}$ and more rapid rates $(>2.3$ $3.2 \mathrm{~mm} / \mathrm{yr}$ ) after $8.7 \mathrm{Ma}$ for the Gold Valley region.

The southeastem Black Mountains were at shallow crustal levels $\left(<300^{\circ} \mathrm{C}\right)$ well before the onset of Tertiary extension with basement biotite cooling ages of 230-235 Ma.

Thermochronology and field relations indicate that $\sim 10 \mathrm{Ma}$ shallow level granitic plutons in the southern Greenwater Range were unroofed shortly after crystallization (by $\sim 9 \mathrm{Ma}$ ).
In the central Black Mountains biotite cooling ages in rocks of both the Precambrian basement and surrounding Miocene plutons young to the northwest indicating diachronous unroofing between 8.5 and 6.7 Ma. Diachronous unroofing was accompanied by dike intrusions which also decrease in age toward the northwest. Biotite ages from $13 \mathrm{Ma}$ to as young as 6.7 Ma from the turtlebacks indicate a midcrustal origin prior to extensional unroofing. Preextensional depths of the order of $10-15 \mathrm{~km}$ and the northwest younging cooling age pattern are consistent with palinspastic reconstructions of Tertiary extension which require $\sim \mathbf{8 0} \mathbf{~ k m}$ of west directed horizontal transport of the Panamint Mountains off the top of the Black Mountains [Stewart, 1983; Snow and Wernicke, 1989].

The cooling age pattern and depth estimates obtained here from across the Black Mountains indicate northwestward detachment with an average initial dip on the order of $20^{\circ}$. Starting with an initially listric geometry, progressive migration of a footwall flexure in the direction of transport (expressed by the diachronous cooling age pattem) accomodates the observations of moderately to steeply dipping Tertiary strata 
in the southeastern Black Mountains [Holm and Wernicke, 1990], and field relations suggesting an earlier high-angle detachment orientation [Miller, 1991], with the low average initial dips obtained here. Mica ages discordant from the overall northwest younging trend (ages from the Amargosa chaos and Badwater turtleback) are explained by northwestward transport of initially shallower crustal levels onto deeper levels along splays of the major detachment zone.
Aknowledgments. This work was supported by a National Science Foundation grant (EAR89-71227) awarded to Brian Wernicke. We thank the National Park Service for allowing sampling and field mapping in the Black Mountains. We thank David West for assistance in the laboratory and discussion, Brian Wernicke for discussion and comments on an early version of the manuscript, and John Bartley and Calvin Miller for thoughtful reviews.

\section{REFERENCES}

Armstrong, R.L., Geochronology of Tertiary igneous rocks, eastem Basin and Range Province, westem Utah, eastem Nevada, and vicinity, U.S.A., Geochsm. Cosmochim. Acta, 34, 203-232, 1970.

Asmerom, Y., J.K. Snow, D.K. Holm, S.B. Jacobsen, B.P. Wemicke, and D.R. Lux, Rapid uplift and crustal growth in extensional environments: An isotopic study from the Death Valley region, Califomia, Geology, 18 223-226, 1990

Bartley, J.M., and B.P. Wemicke, The Snake Range decollement interpreted as a majo extensional shear zone, Tecrontcs, 3, 647659, 1984.

Buck, W.R., Flexural rotation of nomal faults, Tectonics, 7, 959-973, 1988.

Cemen, I., and L.A. Wright. Cenozoic extension in northem Death Valley: evidence from the sedimentary rocks surrounding the Funeral Mountains, Geol. Soc. Am. Abstr. Programs, 20, 149, 1988.

Cemen, L., L.A. Wright, R.E. Drake, and F.C Johnson, Cenozoic sedimentation and sequence of deformational events at the southeastem end of the Fumace Creek strikeslip fault zone, Death Valley region. Califormia, in Strike-Slip Deformation, Basin Formation, and Sedimentation, edited by K.T. Biddle and N. Christie-Blick, Spec. Publ. 37. Soc. Econ. Paleontol. Mineral., 127-141. 1985.

Curry, H.D., "Turtleback" fault surfaces in Death Valley, California (abstract), Geol. Soc. Am. Bull., 49, 1875, 1938.

Davidson, G.F., and L.W. Snee, Resetting of the hornblende $\mathrm{K}$-Ar isotopic system during mylonitization - Implications for direct dating of ductile shear zones (abstract), Eos Trans. AGU, 71, 1662, 1990

DeWitt, E., J.F. Sutter, L.A. Wright, and B.P. Troxel, Ar-Ar chronology of Early Cretaceous regional metamorphism, Funeral Mountains, Califomia-A case study of excess argon, Geol. Soc. Am. Abstr. Programs, 20, A16A17, 1988.

Dokka, R.K., and A.K. Baksi, Thermochronology and geochronology of detachment faults of the Mojave Extensional Belt, Calıfornia: A progress report, Geol. Soc. Am. Abstr. Programs, 20, A16, 1988.

Drewes, H., Geology of the Funeral Peak quadrangle, Califomia, on the eastem flank of Death Valley, U.S.G.S. Prof. Pap. 413, 78 Pp., 1963.

Fleck, R.J., Age and Tectonic Significance of Volcanic Rocks, Death Valley Area, Califomia, Geol. Soc. Am. Bull., 81, 28072816, 1970.

Foster, D.A., T.M. Harrison, C.F. Miller, and K.A. Howard, The ${ }^{40} \mathrm{Ar} /{ }^{39} \mathrm{Ar}$ thermochronology of the eastem Mojave Desert, California, and adjacent westem Arizona with implications for the evolution of metamorphic core complexes, J. Geophys. Res., 95, 20,005-20,024, 1990.

Hamilton, W., Detachment in the Death Valley region, Califomia and Nevada, U.S. Geol. Surv. Bulletin, 1790, 763-771, 1988.
Hammarstrom, J.M., and E.-A. Zen, Aluminum in homblende: An empirical igneous geobarometer, Am. Mineral., 71, 1297-1313, 1986.

Harrison, T.M., and I. McDougall, Investigation of an intrusive contact, northwest Nelson, New Zealand - II. Diffusion of radiogenic and excess ${ }^{40} \mathrm{Ar} /{ }^{39} \mathrm{Ar}$ age spectrum analysis, Geochim. Cosmochim. Acta, 44, 2005-2020, 1980.

Holm, D.K., Initial dip, geometry, and kinematics of detachment faulting in the Death Valley region, Califomia, Geol. Soc. Am. Abstr. Programs, 23, A181, 1991.

Holm, D.K., and R.K. Dokka, Major late Miocene cooling of the middle crust associated with extensional orogenesis in the Funeral Mountains, California, Geophys. Res. Lett., 18, 1775-1778, 1991

Holm, D.K., and D.R. Lux, The Copper Canyon Formation: A record of unroofing and Tertiary folding of the Death Valley Turleback surfaces, Geol. Soc. Am. Abstr. Programs, 23. 35,1991

Holm, D.K., and B.P. Wemicke, Tertiary ductile deformation and uplift of the Black Mountains, Death Valley extended terrain. Califomia (abstract), Eos Trans. AGU, 70, 599, 1989.

Holm, D.K., and B. Wemicke, Black Mountains crustal section, Death Valley extended terrain Califomia, Geology, 18, 520-523, 1990

Holm, D.K., J.K. Snow, and D.R. Lux, Uplift history of the Black Mountains crystalline terrain, Death Valley region, Califomia (abstract), Eos Trans. AGU, 70, 1335, 1989.

Hubbard, M.S., and T.M. Harrison, ${ }^{40} \mathrm{Ar} /{ }^{39} \mathrm{Ar}$ age constraints on deformation and metamorphism in the Main Central Thrus Zone and Tibetan Slab, Eastem Nepal Himalaya, Tectonics, 8, 865-880, 1989. Himalaya, Tectonics, 8, 865-880,
. Experimental calibration of the aluminum-inhomblende geobarometer with application to Long Valley caldera (Califomia) volcanic rocks, Geology, 17, 837-841, 1989.

King, G., and M. Ellis, The origin of large local uplift in extensional regions, Nature, 348 , $689-693,1990$

Lachenbruch, A.H., and J.H. Sass, Models of an extending lithosphere and heat flow in the Basin and Range province, in Cenozoic Tectonics and Regional Geophysics of the Westem Cordillera, edited by R.B. Smith and G.P. Ealon, Mem. Geol. Soc. Am., 152, 209 $250,1978$.

Lux, D.R., ${ }^{40} \mathrm{Ar} /{ }^{39} \mathrm{Ar}$ ages for minerals from the amphibolite dynamothemal aureole, Mont Albert, Gaspe, Quebec, Can. J. Earth Sci., 23, 21-26, 1986

McDougall, I., and T. M. Harrison, Geochronology and Thermochronology by the ${ }^{40} \mathrm{Ar} /{ }^{39} \mathrm{Ar}$ Method, Oxford University Press, New York, 1988.

McKenna, L.W., III, Processes of conlinental extension as viewed from the Death Valley region, California, Ph.D. thesis, 198 Pp., Mass. Inst. of Technol., Cambridge, 1990

McKenna, L.W., and L.W. Snee, Timing of movement and strain rate of Cenozoic extensional faulting in the Death Valley area California, Geol. Soc. Am. Abstr. Programs, 22, A227, 1990.

Meurer, K.J., and T. Pavlis, Evolution of the Black Mountain crustal block, Death Valley, Califomia: two component rotation during Neogene extension (abstract), Eos Trans. $A G U, 72,469-470,1991$.

Miller, M.G., High-angle origin of the currently low-angle Badwater Turtleback fault, Death Valley, Califomia, Geology, 19, 372-375 1991.

Miller, J., and B.E. John, Delached strata in a Tertiary low-angle normal fault terrane, southeastem Califomia: A sedimentary record of unroofing, breaching, and continued slip, Geology, 16, 645-648, 1988.

Noble, L.F., Structural features of the Virgin Spring area, Death Valley, California, Geol. Soc. Am. Bull., 52, 941-1000. 1941.

Otton, J.K., Geology of the central Black Mountains, Death Valley, Califomia: The Turtleback terrane, Ph.D. thesis, 155 pp. University Park, Penn. State Univ., 1977.

Parry, W.T., and R.L. Bruhn, Fluid inclusion evidence for minimum $11 \mathrm{~km}$ vertical offset on the Wasalch fault, Utah, Geology, 15, 67$70,1987$.

Richard, S.M., J.E. Fryxell, and J.F. Sutter, Tertiary structure and thermal history of the Harquahala and Buckskin Mountains, westcentral Arizona: Implications for denudation by a major detachment fault system, $J$. Geophys. Res, 95, 19,973-19,989, 1990

Smith, R.B., and R.L. Bruhn, Intra-plate extensional tectonics of the eastem Basin and Range: Inferences of structural style from seismic reflection data, regional tectonics and thermal-mechanical models of brittle-ductile deformation, J. Geophys. Res., 89, 57335762, 1984.

Snow, J.K., and B. Wernicke, Uniqueness of geological correlations: An example from the Death Valley extended terrain, Geol. Soc. Am. Bull., 101, 1351-1362, 1989.

Stewart, J.H., Extensional tectonics in the Death Valley area, Califomia: Transport of the Panamint Range structural block $80 \mathrm{~km}$ northwestward, Geology, 11, 153-157, 1983.

Streitz, R., and M.C. Stinson, (compilers), Death Valley sheet, Geologic map of California, scale 1:250,000, Calif. Div.of Mines and Geol., Sacramento, 1974.

Wemicke, B., and G.J. Axen, On the role of isostasy in the evolution of normal faul systems, Geology, 16, 848-851, 1988.

Wemicke, B., G.J. Axen, and J.K. Snow, Basin and Range extensional tectonics at the latitude of Las Vegas, Nevada, Geol. Soc. Am. Bull., 100. 1738-1757, 1988.

Wright, L.A., Overview of the role of strike-slip and normal faulting in the Neogene history of the region northeast of Death Valley, Califomia - Nevada, in Late Cenozoic Evolution of the Southem Great Basin, Open File 89-1, edited by M.A. Ellis, pp. 1-12, Nev. Bur. of Mines and Geol., Reno, 1989.

Wright, L.A., and B.W. Troxel, Geology of the 
northem half of the Confidence Hills 15' quadrangle, Death Valley region, eastem Califomia: The area of the Amargosa chaos, Cal. Div. of Mines and Geol., map sheet 34 scale 1:24,000, Sacramento, 1984.

Wright, L.A., J.K. Otton, and B.W. Troxel, Turtleback surfaces of Death Valley viewed as phenomena of extension. Geology, 2, 53-54, 1974a.

Wright, L.A., B.W. Troxel, E.G. Williams, M.T Roberts, and P.E. Diehl, Precambrian Sedimentary Environments of the Death Valley Region, Easiem Califomia, Fieldtrip 1, Death Valley Region, Califomia and Nevada Guidebook, pp. 27-35, Geol. Soc. of
Am., Cordilleran Section, Las Vegas, Nevada, 1974b.

Wright, L.A., R.E. Drake, and B.W. Troxel, Evidence for westward migration of sever Cenozoic extension, southeastem Great Basin, Califomia, Geol. Soc. Am. Abstr. Programs, 16, 701, 1984.

Wright, L.A., L. Serpa, and B.W. Troxel, Tectono-chronologic model for wrench fault related crustal extension, Death Valley area, Califomia, Geol. Soc. Am. Abstr. Programs, 19, 898-899, 1987.

Wright, L.A., et al., Cenozoic magmatic and tectonic evolution of the east-central Death Valley region, Califomia, Geological Excursions in Southem California and
Mexico, Guidebook edited by M.J.

Walawender and B.B. Hanan, Geol. Soc. of Am. Annual Meeting, San Diego, California, pp. 93-127, 1991.

D.K. Holm, Department of Geology, Kent Stale University, Kent, Ohio $\mathbf{4 4 2 4 2 .}$

D.R. Lux, Department of Geology,

University of Maine, Orono, Maine 04469.

J.K. Snow, Division of Geology and

Planetary Sciences, California Institute of

Technology, Pasadena, Califomia 91125.

(Received August 20, 1991

revised December 6, 1991

accepted January 23, 1992. ) 